\title{
Ávöxtun íslenskra hlutabréfa á uppgjörstíma
}

\author{
Gylfi Magnússon ${ }^{1}$
}

\begin{abstract}
Ágrip
Ávöxtun hlutabréfa, sem skráð eru í Kauphöll Íslands, hefur nokkur sérkenni um mánaðamót, ársfjórðungamót og áramót. Hlutabréf hækka að jafnaði umtalsvert í verði síðasta viðskiptadag mánaðar en lækka svo aftur fyrsta viðskiptadag mánaðar. Pessi sérkennilega verðpróun kemur skýrar fram við ársfjórðungamót en önnur mánaðamót og skýrast við áramót. Vel er pekkt erlendis úr fyrri rannsóknum að ávöxtun hlutabréfa er sérkennileg við mánaðamót en mynstur eins og pað íslenska virðist pó ekki algengt. Ein skýring pessa mynsturs getur verið sú að aðilar á markaðinum sjái sér hag í að ýta verði hlutabréfa upp rétt fyrir uppgjörstíma. Verðpróun innan dags er pó ekki með peim hætti sem við væri að búast ef sú væri raunin. Önnur hugsanleg skýring er að einhverjir markaðsaðilar sjái sér hag í að auka vægi hlutabréfa í söfnum sínum á pessum tímamótum.
\end{abstract}

\begin{abstract}
The return on stocks that are listed on the Icelandic Stock Exchange has a few unusual characteristics in the trading days around the turn-of-the-month, quarter or year. The price of stocks rises on average significantly in the last trading day of the month and then declines again in the first trading day of the month. This trend is more pronounced at quarter-ends and year-end than other months. It is well known from previous research on other stock markets that the return on stocks is unusual around the turn-of-the-month but a pattern like the Icelandic one does not seem common. One possible explanation is that some market participants try to raise the price of stocks right before the end of a period. The pattern of price changes during the day is however such that this explanation seems rather unlikely. Another possible explanation is that some market participants have a tendency to increase their holding of stocks on the last trading day of a period.
\end{abstract}

JEL-flokkun: G12; G14

Lykilhugtök: hlutabréfaverð, skilvirkni, mánaðamót, íslenskur hlutabréfamarkaður

\footnotetext{
1 Höfundur er dósent í viðskipta- og hagfræðideild Háskóla Íslands. Hann sat í stjórn Kauphallar Íslands frá 2004 til 2006. Pær niðurstöður og skoðanir sem settar eru fram í greininni eru eingöngu á ábyrgð höfundar en ekki peirra aðila sem hann vinnur fyrir, hefur unnið fyrir eða tengist með öðrum hætti. Höfundur vill pakka tveimur ónafngreindum ritrýnum gagnlegar ábendingar og jafnframt pakka pátttakendum á málstofu viðskipta- og hagfræðideildar par sem rannsóknin var kynnt og hlaut góða umræðu.
} 


\section{Inngangur}

Íslenski hlutabréfamarkaðurinn sker sig talsvert úr öðrum mörkuðum pegar verðpróun hlutabréfa um mánaðamót er skoðuð. Sérstaðan er enn skýrari pegar einnig er um ársfjórðunga- eða áramót að ræða. Í pessari rannsókn er pessi verðpróun á íslenska markaðinum skoðuð, bæði fyrir markaðinn í heild og einstök fyrirtæki, og hún borin saman við niðurstöður fyrir fjölmarga erlenda hlutabréfamarkaði. Sérstaklega er skoðað hvort túlka megi niðurstöðurnar sem vísbendingu um markaðsmisnotkun, par sem verð hlutabréfa er hækkað með viðskiptum í lok tímabils, til að bæta stöðu í uppgjöri.

\section{Fyrri rannsóknir}

Sérkennileg verðpróun hlutabréfa um mánaðamót hefur verið pekkt lengi. Ariel (1987) benti á mikinn mun á ávöxtun bandarískra hlutabréfa eftir pví hvort fyrri eða síðari helmingur mánaðarins er skoðaður. Í peim gögnum sem hann skoðaði fyrir árin 1963 til 1981 var ávöxtun jákvæð fyrri hluta mánaðar en nánast engin síðari hluta mánaðarins. Síðari rannsókn (Lakonishok og Smidt, 1988) leiddi í ljós að umframávöxtunin sem veldur pessum mun kemur yfirleitt fram á styttri tíma, nánar tiltekið á síðasta viðskiptadegi mánaðar og fyrstu premur viðskiptadögum mánaðar en Ariel taldi síðasta viðskiptadag mánaðar með fyrri hluta mánaðar.

Prátt fyrir að vitað hafi verið um pessi sérkenni í verðpróun allt frá níunda áratug síðustu aldar virðast pau enn koma fram á fjölmörgum mörkuðum. Kunkel, Compton og Beyer (2003) skoða hlutabréfamarkaði í 19 löndum og finna merki um umframávöxtun við mánaðamót á 15 peirra. Í peim 15 löndum komu 87\% allrar ávöxtunar fram fyrrnefnda fjóra viðskiptadaga.

Erfiðlega hefur gengið að finna skýringar á pessum sérkennum. Ogden (1990) setur fram pá tilgátu að verðpróunina megi rekja til viðskiptavenja og reglna sem valda sveiflum í greiðsluflæði á ýmsum mörkuðum um mánaðamót. Nánar tiltekið bendir Ogden á að um mánaðamót sé venjan að greiða út laun og að einnig sé algengt að vextir séu greiddir út um mánaðamót. Viðtakendurnir hafi pví óvenjumikið laust fé á pessum tímamótum og ef peir nota hluta pess til kaupa á hlutabréfum geti pað skýrt aukna spurn eftir slíkum bréfum og verðhækkun peirra á peim tíma.

Ýmsir (sjá t.d. Allen og Saunders, 1992, Lee, Porter og Weaver, 1998, Griffiths og Winters, 2005, Morey og Neal, 2006) hafa skoðað tilhneigingu sjóðstjóra til að breyta samsetningu sjóða sinna rétt fyrir áramót eða önnur uppgjörstímabil. Pað er m.a. gert í peim tilgangi að láta líta út fyrir að sjóðirnir taki minni áhættu en peir gera alla jafna eða til að losna við bréf sem hafa skilað lágri ávöxtun og kaupa í peirra stað bréf sem hafa skilað góðri ávöxtun, til að svo virðist sem sjóðstjórinn hafi veðjað á eignir sem stóðu sig vel. Á ensku hefur petta fyrirbæri verið kallað window dressing eða gluggaskreyting og er pá verið að vísa til pess að með slíkum tilfæringum takist sjóðstjórum að láta eignasamsetningu sjóðsins líta vænlega út í stuttan tíma, pegar hún er gerð opinber fyrir eigendur og tilvonandi viðskiptavini.

Ef mikið er um slíkar tilfæringar vegna gluggaskreytinga ættu pær að geta skýrt einhverjar breytingar á verði ýmissa eigna, pannig að pær lækki sem sjóðstjórar vilja 
helst ekki sýna á bókum sínum en aðrar hækki. Sérstaklega hefur petta verið notað til að skýra háa ávöxtun hlutabréfa í janúarmánuði. ${ }^{2}$

Engin fyrrgreindra rannsókna hefur leitt í ljós svipað mynstur í hlutabréfaverði og pessi rannsókn á íslenska markaðinum, p.e. að verð hækki rétt fyrir mánaðamót eða önnur tímamót og lækki síðan aftur rétt á eftir. Slíku mynstri er hins vegar lýst í grein Carhart o.fl. (2002). Carhart og félagar skoða ávöxtun bandarískra hlutabréfasjóða, eins og hún mældist í vísitölum Lippers árin 1992 til 2000. ${ }^{3}$ Peir finna skýr merki um að sjóðirnir hafi verið ofmetnir í lok hvers ársfjórðungs og sérstaklega í árslok en matið síðan lækkað strax á eftir. Peir segja sjóðina ofmetna vegna pess að eignir sjóðanna virðast í mörgum tilfellum hafa verið skráðar á pessum tímamótum á dagslokaverði sem var óeðlilega hátt, hærra en að jafnaði næstu daga á undan og eftir. Hins vegar finna peir lítil eða engin merki pess að sjóðirnir séu ofmetnir af sömu ástæðu í lok annarra mánaða.

Pegar verðpróun eigna sjóðanna innan síðasta dags ársfjórðungs er skoðuð kemur í ljós að verðhækkunin er langmest síðasta hálftímann fyrir lokun markaða. Einkum virðist sem verð hlutabréfa í fyrirtækjum með lítið markaðsvirði hækki pennan síðasta viðskiptadag ársfjórðungs en pví meira sem markaðsvirði fyrirtækja er peim mun minni er hækkunin. Að jafnaði hækka bréf í hlutabréfum fyrirtækja sem eru í lægsta fimmtunginum ef peim er raðað eftir markaðsvirði um ríflega 100 punkta síðasta hálftíma hvers árs og um 26 punkta á sama tíma í lok annarra ársfjórðunga. Hlutabréf peirra fyrirtækja sem eru í efsta fimmtungnum hækka einungis um örfáa punkta á sama tíma. Höfundarnir telja petta sterka vísbendingu um að sjóðstjórar séu að breyta verði sér í hag í blálokin á hverju tímabili, senda inn kauptilboð í bréf fyrirtækja sem auðvelt er að hreyfa verð á, til að ýta upp dagslokaverðinu og par með verðmati á viðkomandi bréfum sem eru í eigu sjóðanna. Slíkar tilraunir til að hafa áhrif á verð eru bannaðar með lögum í flestum löndum, p.á m. Bandaríkjunum. ${ }^{4}$

Sambærilegar rannsóknir á íslenskum markaði hafa ekki verið birtar en Stefán B. Gunnlaugsson (2003) kannaði hvort munur væri á ávöxtun úrvalsvísitölunnar íslensku eftir mánuðum eða vikudögum eða hvort hún væri óvenjuleg rétt fyrir eða

2 Banz (1981) sýndi fram á að ávöxtun smærri fyrirtækja í Bandaríkjunum var sögulega nokkuð hærri en stórra fyrirtækja. Rannsóknir sem unnar hafa verið í kjölfarið (Keim, 1983, Reinganum, 1983, og margar síðari rannsóknir) hafa sýnt að pessi umframávöxtun smárra fyrirtækja kemur öll fram í janúarmánuði og veldur pví að hlutabréf í Bandaríkjunum skila meiru í peim mánuði að jafnaði en öðrum mánuðum. Ýmsar skýringar hafa verið nefndar á pessu. Fyrst var einkum horft til skattareglna en með pví að selja bréf sem höfðu lækkað og innleysa pannig tap fyrir áramót er hægt að fresta skattgreiðslum vegna hagnaðar á öðrum bréfum (sjá t.d. Poterba og Weisbenner, 2002). Leidd hafa verið rök að pví að petta bitni á verði smárra fyrirtækja fyrir áramót en pau hækki síðan aftur strax eftir áramótin, pegar fjárfestar vilja bæta peim aftur í söfn sín. Síðar hafa aðrir bent á að gluggaskreytingar geti haft svipuð áhrif, valdið lækkun rétt fyrir áramót og hækkun eftir áramót.

${ }^{3}$ Lipper er hluti af Reuter-samstæðunni. Fyrirtækið reiknar fyrrnefndar vísitölur út með pví að skipta fjárfestingarstefnu bandarískra verðbréfasjóða (mutual funds) upp í nokkra flokka og reikna síðan heildarávöxtun nokkurra af stærstu sjóðunum í hverjum flokki.

${ }^{4}$ Petta flokkast undir markaðsmisnotkun og er einnig ólöglegt á Íslandi, sbr. 55. gr. laga um verðbréfaviðskipti, nr. 33/2003. 
eftir frídaga vegna hátíða. Byggt var á daglegum breytingum vísitölunnar frá upphafi, p.e. áramótum 1992-1993, til maí 2003.

Niðurstöðurnar eru áhugaverðar. Í öllum tilfellum sem skoðuð eru er ávöxtun jákvæð dagana fyrir hátíðir en neikvæð rétt á eftir, munurinn er pó lítill fyrir og eftir jól. Áhrif áramóta eru mest en síðasta viðskiptadag ársins er ávöxtun um 13 sinnum meiri en aðra daga að jafnaði. Pegar Kruskal-Wallis prófinu er beitt kemur í ljós að munurinn á ávöxtun fyrir og eftir hátíðir er tölfræðilega marktækur.

Stefán nefnir sem hugsanlega skýringu á pví hve mikið bréf hækka síðasta viðskiptadag ársins að fjárfestar sjái sér hag í að ýta upp hlutabréfaverði pennan dag til að hafa áhrif á uppgjör verðbréfaeignar sinnar um áramót. Pá bendir hann á að mikil hlutabréfakaup einstaklinga meðan peir gátu enn fengið skattafslátt vegna peirra geti einnig verið hluti af skýringunni. Stefán telur pó að ekki sé hægt að fullyrða að hegðan pátttakenda á íslenskum hlutabréfamarkaði hafi verið óeðlileg um áramót, pótt ýmislegt bendi til pess, pörf sé frekari rannsókna.

Frosti Ólafsson (2006) skoðaði almanaksáhrif á íslenskum hlutabréfamarkaði með svipuðum aðferðum og Stefán, línulegri aðhvarfsgreiningu og Kruskal-Wallis prófi. Í rannsókn Frosta var horft á ávöxtun úrvalsvísitölunnar frá janúar 1996 til desember 2005. Ferns konar almanaksáhrif voru skoðuð, áhrif vikudaga og mánaða og ávöxtun fyrir og eftir frídaga og mánaðamót.

Niðurstöður Frosta voru m.a. að föstudagar sýndu marktækt betri ávöxtun en aðrir dagar og ekki var tölfræðilega marktækur munur á ávöxtun eftir mánuðum. Ávöxtun reyndist að jafnaði góð fyrir frídag en slæm eftir frídag en pó átti pað ekki við um alla frídaga. Hæst var ávöxtun fyrir áramót en verst eftir 1. maí. Áhugaverðasta niðurstaðan fékkst pó pegar ávöxtun fyrir og eftir mánaðamót var könnuð. Síðasti viðskiptadagur hvers mánaðar reyndist að jafnaði skila mestri ávöxtun en fyrsti viðskiptadagur minnstri ávöxtun.

Vikuritið Vísbending (2006) bar saman ávöxtun á seinni hluta ársfjórðungs annars vegar og peim fyrri hins vegar fyrir 27 ársfjórðunga. Í ljós kom að meðalhækkunin var 3\% fyrri helming hvers ársfjórðungs en 2,7\% pann síðari. Í greininni er fullyrt að раð orð hafi stundum farið af íslenska markaðinum að bréf hækki mikið í verði skömmu áður en uppgjörstímabili lýkur. Greinarhöfundur telur pó að ekki hafi verið lagðar fram vísbendingar um sterka leitni í slíka veru.

Í Kauphallartíðindum (2006) er skoðuð hækkun úrvalsvísitölunnar eftir vikudögum og mánaðardögum frá ársbyrjun 1998 til miðs ágúst 2006. Fram kemur að vísitalan virðist hækka örlítið meira að meðaltali hvern dag eftir pví sem líður á vikuna og er meðalhækkun á föstudögum 0,2\% en nær engin fyrstu tvo daga vikunnar. Svipað mynstur er leitt í ljós pegar mánaðardagar eru skoðaðir, örlítil leitni er upp á við pegar líður á mánuðinn. Greinarhöfundur skiptir mánuðinum í prennt, p.e. 1.-10., 11.-20. og 21.-31. dag hvers mánaðar. Meðaltalsdagshækkunin mælist lægst fyrsta priðjung mánaðarins skv. pessari skiptingu eða $0,04 \%$ en hæst $0,12 \%$ á miðjutímabilinu. Síðasta priðjung mánaðarins er hún síðan örlítið lægri eða 0,09\% á dag að jafnaði. Svipað mynstur kemur í ljós pegar skoðað er hve marga daga af heildinni vísitalan hækkar. Petta telur greinarhöfundur sýna að ekki sé um áberandi hækkanir í lok mánaðar að ræða, eins og stundum sé haldið fram. 
Fyrrnefndar greinar í Vísbendingu og Kauphallartíđindum vísa báðar til orðróms um markaðsmisnotkun á Íslandi. Fleiri dæmi má finna í fjölmiðlum par sem rætt er um slíkan orðróm. Pau dæmi eru pó ekki mörg.

Reikningsskilanefnd Félags löggiltra endurskoðenda (1991, 1995 og 1998) hefur nokkuð fjallað um mat á verðmæti hlutabréfa og sérstaklega hvort miða eigi við síðasta viðskiptaverð eða annað verð. Árið 1991 voru ekki hafin viðskipti með hlutabréf á Verðbréfapingi en talsverð viðskipti voru hins vegar með óskráð bréf fyrir milligöngu fjármálafyrirtækja sem birtu opinberlega bæði kaup- og sölutilboð í hlutabréf nokkurra fyrirtækja. Vandamál vegna strjálla viðskipta voru m.a. til skoðunar árið 1995 og pá kom nefndin með tillögu um að tekið yrði mið af verði í viðskiptum síðustu tveggja mánaða við mat á verðmæti í lok uppgjörstímabils:

Viðmiðunargengi hlutabréfa í félögum, sem skráð eru á Verðbréfapingi Íslands og Opna tilboðsmarkaðnum skal vera vegið meðaltal viðskipta í hverju einstöku félagi síðustu tvo mánuði fyrir reikningsskiladag. Sé lokaverð eða hagstæðasta sölutilboð í lok tímabilsins lægra en meðalgengi ber að miða við pað verð sem lægst er. Pó ber að hafa í huga, ef viðskipti eru lítil og síðasta viðskiptaverð eða sölutilboð er verulega frábrugðið meðalgengi síðustu tveggja mánaða og í ljós kemur eftir lok tímabilsins að pað verð er ekki viðeigandi ber að horfa fram hjá peim viðskiptum.

(Reikningsskilanefnd FLE 1995)

\section{Gögn}

Við rannsókn pessa var einkum stuðst við gögn frá Kauphöll Íslands. Skoðuð voru gögn um úrvalsvísitöluna (ICEX-15), bæði með og án arðs, frá upphafi, p.e. frá ársbyrjun 1993 til ársins 2007 með fyrstu premur viðskiptadögum pess árs, og gögn um heildarvísitölu (ICEX-Main) fyrir sama tímabil. Kauphöllin hætti útreikningi á arðsleiðréttum vísitölum 27. október 2000 og hóf hann ekki aftur fyrr en 1. apríl 2004. Vegna pess purfti að reikna arðsleiðrétta úrvalsvísitölu fyrir pað tímabil sem upp á vantar sérstaklega. Porbergur Pórsson hagfræðingur vann mest af pví starfi undir handleiðslu greinarhöfundar út frá gögnum frá Kauphöllinni og eru honum færðar pakkir fyrir gott starf. Fengin voru gögn um veltu og fjölda viðskipta með hlutabréf í Kauphöllinni frá apríl 1991 til nóvember 2006. Pá fengust gögn um dagslokaverð frá upphafi allra fyrirtækja sem skráð voru í Kauphöllina í upphafi árs 2006 eða fengu skráningu á pví ári. Loks voru fengin gögn um breytingar á úrvalsvísitölunni innan dags, frá 16. febrúar 2004 og fram yfir áramótin 2006 til 2007. Pau gögn eru fengin með pví að skrá allar breytingar sem verða á vísitölunni pegar gengi á bréfum í einhverju fyrirtækjanna í vísitölunni breytist ${ }^{5}$, pó aldrei pannig að minna en 30 sekúndur líði á milli skráninga. Samtals voru skráð ríflega 150 púsund gildi fyrir vísitöluna pennan tíma eða að jafnaði eitt verð fyrir hverjar 102 sekúndur.

Starfsfólki Kauphallarinnar, sérstaklega peim Brynjari Erni Ólafssyni og Magnúsi Harðarsyni, eru færðar pakkir fyrir ómetanlega aðstoð við að útvega öll pessi gögn.

\footnotetext{
${ }^{5}$ Vegna pess að hluta tímabilsins var fyrirtæki (Atlantic Petroleum) í vísitölunni sem skráir hlutabréf sín í erlendri mynt (dönskum krónum), pá gat vísitalan líka breyst vegna pess að gengi dönsku krónunnar gagnvart peirri íslensku breyttist.
} 
Einnig voru skoðaðar erlendar hlutabréfavísitölur til að bera saman við íslensku niðurstöðurnar. Flestar peirra voru fengnar af vef Yahoo - Finance. ${ }^{6}$ Alls voru fengin gögn um 28 vísitölur paðan en fjórum peirra var sleppt vegna pess að ekki voru til gögn um pær nema fyrir hluta pess tímabils sem til skoðunar var. Til viðbótar pessum vísitölum voru prjár baltneskar hlutabréfavísitölur og ein sænsk sóttar á vef OMX.7 Erlendu vísitölurnar voru skoðaðar fyrir tímabilið frá síðasta viðskiptadegi 1999 til fyrstu priggja viðskiptadaga ársins 2007. Í nokkrum tilfellum voru pó ekki til gögn nema frá ársbyrjun 2000.

Tölur um innlenda vexti voru fengnar af vef Seðlabanka Íslands. ${ }^{8}$ Loks voru skoðaðar allar fréttir í gagnasafni Morgunblaðsins frá 1987 til loka árs 2006 par sem orðið markaðsmisnotkun kemur fyrir og leitað að fleiri dæmum í ýmsum gagnagrunnum, p.á m. á heimasíðu Kauphallar, Fjármálaeftirlits, Hæstaréttar og héraðsdómstóla.

\section{Markaðsmisnotkun á Íslandi}

Sem fyrr segir er markaðsmisnotkun óheimil á Íslandi, líkt og í nágrannalöndunum. Eftirlitsaðilar, fyrst og fremst Kauphöllin og Fjármálaeftirlitið, reyna að koma í veg fyrir hana með ýmsum aðferðum, m.a. að fylgjast með mörkuðum og skoða pau viðskipti sem teljast á einhvern hátt óvenjuleg. Notar Kauphöllin vegna pessa sérstakt eftirlitskerfi, kallað SMARTS. ${ }^{9}$

Nokkur dæmi um meinta markaðsmisnotkun hafa komið upp á undanförnum árum. Nær aldrei hafa pau mál pó endað fyrir dómstólum. ${ }^{10}$ Ekki er gott að fá mynd af pví í hvaða tilfellum grunur hefur kviknað um markaðsmisnotkun en ákveðið hefur verið af eftirlitsaðilum að beita ekki viðurlögum og að vísa málinu ekki til annarra yfirvalda pví að alla jafna er ekki upplýst opinberlega um slíkt. Hér verður ekki reynt að gefa tæmandi yfirlit um pau mál af pessum toga sem rædd hafa verið opinberlega en nokkur dæmi tekin.

Árið 2001 ákvað Kauphöllin að lækka dagslokaverð á bréfum í ÚA pann 29. júní, í lok annars ársfjórðungs, úr 4,00 í 3,20. Sú ástæða var gefin að síðustu viðskipti pann dag, fyrir um 2,4 milljónir króna, hefðu gefið villandi mynd af verði bréfanna en við pau viðskipti hækkaði skráð verð um 25\%, úr 3,20 í 4,00.11 Í kjölfarið sendi

\footnotetext{
${ }^{6}$ http://finance.yahoo.com.

7 http://www.omxgroup.com.

${ }^{8}$ http://www.sedlabanki.is.

${ }^{9}$ Á vef Kauphallarinnar (http://www.icex.is/is/smarts) stendur m.a. um petta kerfi: „Í byrjun mars 2003 var Kauphöllinni formlega afhent eftirlitskerfið SMARTS til notkunar ... SMARTS er með fullkomnustu eftirlitskerfum sem völ er á. Kerfið eykur getu Kauphallarinnar til að koma auga á óvenjulegar hreyfingar í viðskiptakerfinu en einnig auðveldar SMARTS greiningu á slíkum hreyfingum. ... [T]ilkoma SMARTS styrkir samstarf í eftirlitsmálum milli NOREX kauphallanna, sem allar nota kerfið ... Kauphöllin mun ekki gefa nákvæmlega upp hvers konar bjöllur eru virkar í kerfinu, p.e. hvað er skilgreint sem óvenjuleg hegðun. Öllum markaðsaðilum má pó vera ljóst að pær eru skilgreindar m.a. út frá verðhreyfingum, stærð viðskipta og hvort viðskipti eru tilkynnt tímanlega til Kauphallarinnar. Hins vegar eru einnig flóknari bjöllur sem m.a. lúta að innherjaviðskiptum. "

10 Í riti Jóhannesar Sigurðssonar (2005) um dóma í verðbréfamarkaðsrétti frá 1980 til 2005 er ekki tilgreindur neinn dómur vegna markaðsmisnotkunar.

11 Gengi ÚA hinn 29. júní lækkað. Morgunblaðið, 17. júlí 2001.
} 
Kauphöllin frá sér tilkynningu par sem m.a. kom fram að fleiri viðskipti í lok annars ársfjórðungs pessa árs hefðu verið til athugunar en einungis hefði verið gripið til pess ráðs að breyta dagslokaverði í einu tilfelli.

Árið 2003 urðu talsverð viðskipti með hlutabréf Skeljungs pann 30. júní, síðasta viðskiptadag annars ársfjórðungs. Um priðjungur hlutafjár skipti um eigendur. Í kjölfarið var tekist á um hvort tilkynnt hefði verið með eðlilegum hætti um pessi viðskipti til Kauphallarinnar og jafnframt hvort verð í viðskiptunum hefði verið eðlilegt. Fjármálaeftirlitið tók málið til rannsóknar og vísaði hluta pess til ríkislögreglustjóra. ${ }^{12}$

Árið 2003 var maður dæmdur í eins árs skilorðsbundið fangelsi í Héraðsdómi Reykjavíkur fyrir ýmis brot í starfi sem sjóðstjóri. Einn angi pess máls fólst í markaðsmisnotkun. Maðurinn hafði lagt fram tilboð í Kauphöll í nafni sjóða par sem hann bauð hærra en markaðsverð, í peim tilgangi að hækka skráð verð.

Árið 2005 vaknaði grunur um markaðsmisnotkun vegna viðskipta með skuldabréf Íbúðalánasjóðs rétt fyrir lokun markaða á útboðsdegi skuldabréfa sjóðsins pann 22. nóvember. Eftir að hafa fengið skýringar á viðskiptunum ákvað Fjármálaeftirlitið að hafast ekkert frekar að vegna málsins. ${ }^{13}$

\section{5. Ávöxtun íslenskra hlutabréfa um mánaðamót}

Íslensk hlutabréf hækka að jafnaði síðasta viðskiptadag hvers mánaðar talsvert meira en á meðaldegi en lækka síðan aftur fyrsta viðskiptadag hvers mánaðar. Frávikin frá meðalávöxtun eru enn meiri síðasta og fyrsta viðskiptadag hvers ársfjórðungs og mest pegar síðasti eða fyrsti viðskiptadagur hvers árs er skoðaður. Pau mánaðamót sem ekki eru ársfjórðungamót eru frávikin frá meðalávöxtun talsvert minni. Ef tímabilinu frá upphafi árs 1993, en fyrstu gildi úrvalsvísitölunnar ná til pess tíma, er skipt í tvennt, annars vegar 1993 til og með 1999 og hins vegar 2000 til og með 2006 sést að pessi sérkenni ávöxtunar við mánaðamót eru mun meiri síðustu ár en á upphafsárum markaðarins. ${ }^{14}$ Fyrstu árin er engin merki pessara sérkenna að finna nema e.t.v. um áramót. Í ljósi pess um hve fá áramót er að ræða er pó óvarlegt að draga ályktanir af litlu fráviki í ávöxtun síðasta viðskiptadag ársins á fyrri hluta tímabilsins. ${ }^{15}$

${ }^{12}$ Markaðsmisnotkun? Morgunblaðið, 29. janúar 2004.

13 Fréttatilkynning Fjármálaeftirlitsins pann 19. janúar 2006, birt á vef eftirlitsins, http://www.fme.is.

14 Ávöxtun síðasta viðskiptadag ársins 1999 er talin með síðara tímabilinu í pessari skiptingu hér og annars staðar í greininni. Jafnframt eru fyrstu prír viðskiptadagar ársins 2007 taldir með síðara tímabilinu. Petta var m.a. gert til að fá jafnmörg dæmi um síðasta dag fyrir áramót og fyrsta dag eftir áramót á síðara tímabilinu.

${ }^{15}$ Fram til loka árs 2002 gátu einstaklingar fengið skattafslátt vegna kaupa á hlutabréfum. Algengt var að bréfin væru keypt undir lok ársins, jafnvel síðasta viðskiptadag ársins. Раð hefur verið nefnt (Stefán Gunnlaugsson, 2003) sem hugsanleg skýring á mikilli ávöxtun pann dag. Vegna pessa var athugað sérstaklega hvort breyting hefði orðið á ávöxtun pennan dag pegar afslátturinn féll niður. Hafa ber í huga að einungis 4 áramót hafa verið síðan og pví rétt að túlka meðaltöl varlega. Pó virðist óhætt að fullyrða að ekki eru neinar sérstakar vísbendingar um að skattafslátturinn hafi skipt sköpum fyrir ávöxtun síðasta viðskiptadag 
Í töflu 1 (aftast) má sjá meðalávöxtun ${ }^{16}$ um pessi tímamót fyrir úrvalsvísitöluna (ICEX-15), með og án arðs, og heildarvísitölu aðallista (ICEX-Main). Vegna pess hve niðurstöðurnar eru líkar fyrir allar prjár vísitölurnar verður hér látið nægja að fjalla um tölurnar fyrir úrvalsvísitöluna með arði. Eins og sjá má var meðalávöxtun peirrar vísitölu síðasta viðskiptadag hvers mánaðar árin 2000 til 2006 0,35\%, pá mánuði sem einnig voru ársfjórðungamót var meðalávöxtunin 0,71\% síðasta daginn og síðasta viðskiptadag ársins var ávöxtunin $0,87 \%$. Pau mánaðamót sem ekki voru ársfjórðungamót var meðalávöxtunin $0,17 \%$ síðasta daginn. Til samanburðar er meðalávöxtun allra daga sama tímabil einungis 0,091\%. Staðalfrávik daglegrar ávöxtunar petta tímabil var 0,94\% pannig að meðaltalsávöxtun síðasta dag hvers mánaðar er frá pví að vera um 0,09 staðalfrávikum fyrir ofan meðaltal, pau mánaðamót sem ekki eru ársfjórðungamót, upp í að vera 0,83 staðalfrávikum fyrir ofan meðaltal, um áramót.

Fyrsta viðskiptadag hvers mánaðar snúast pessar tölur svo við, pá er ávöxtunin á bilinu 0,36 (um venjuleg mánaðamót) og upp í 0,53 (um ársfjórðungamót) staðalfrávikum fyrir neðan meðaltal.

Ýmsum aðferðum má beita til að skoða hvort pessi frávik í ávöxtun eru tölfræðilega marktæk. Í töflu 2 eru birt $t$-gildi fyrir frávik frá hefðbundnu meðaltali, skv. reiknireglunni:

$$
\text { (j.1) } \quad t_{d}=\frac{\bar{x}_{d}-\bar{x}_{\text {alls }}}{\sqrt{\frac{s_{d}^{2}}{n_{d}}+\frac{s_{\text {alls }}^{2}}{n_{\text {alls }}}}}
$$

Hér táknar $\bar{X}$ meðalávöxtun, $s$ staðalfrávik, $d$ vísar til viðkomandi tegundar dagsetningar (t.d. síðasti viðskiptadagur hvers mánaðar) og $n$ er fjöldi mælinga fyrir sambærilega daga.

Tafla 2. t-gildi fyrir frávik í ávöxtun.

\begin{tabular}{lcc}
\hline & Síðasti & Fyrsti \\
\hline Mánaðamót & 2,23 & $-3,40$ \\
Ársfjórðungamót & 4,22 & $-2,29$ \\
Áramót & 4,37 & $-0,73$ \\
Venjuleg mánaðamót & 0,69 & $-2,52$ \\
\hline
\end{tabular}

Раð flækir nokkuð túlkun $t$-gildanna að ávöxtun vísitölunnar er ekki normaldreifð, pótt pau sex gildi sem virðast tölfræðilega marktæk séu pað fjarri 0 að ólíklegt megi teljast að skýra megi pau sem tilviljun, pótt ávöxtunin sé ekki normaldreifð. ${ }^{17}$ Vegna

ársins. Meðalávöxtun úrvalsvísitölunnar pann dag 1993 til 2002 var 0,55\% en frá 2003 til og með 2006 var hún $0,60 \%$.

${ }_{16}$ Reiknað er hefðbundið (arithmetic) meðaltal í öllum tilfellum.

${ }^{17}$ Fyrir pað tímabil sem hér er til skoðunar mælist reisn (kurtosis) vísitölunnar 3,44 og skekkja (skewness) -0,31. Dreifingin er pví aðeins skekkt til vinstri og með mun pykkari hala en normaldreifing. Jarque-Bera próf staðfestir að pví fer fjarri að ávöxtun vísitölunnar sé normaldreifð. 
pessa var einnig beitt Mann-Whitney-Wilcoxon (MWW) prófi en pað byggist ekki á normaldreifingu sem forsendu. Reiknaðar voru út líkur á hverju fráviki fyrir sig skv. prófinu, p.e. líkur á að fá pennan mun á úrtaksmeðaltali, ef raunverulegt meðaltal ávöxtunar væri hið sama alla daga. Niðurstöðurnar eru birtar í töflu 3.

Tafla 3. Líkur á fráviki í ávöxtun skv. MWW-prófi.

\begin{tabular}{lcc}
\hline & Síðasti & Fyrsti \\
\hline Mánaðamót & $0,35 \%$ & $0,01 \%$ \\
Ársfjórðungamót & $0,01 \%$ & $0,14 \%$ \\
Áramót & $0,20 \%$ & $9,15 \%$ \\
Venjuleg mánaðamót & $28,03 \%$ & $0,78 \%$ \\
\hline
\end{tabular}

Niðurstöðurnar í töflu 3 eru mjög á sömu leið og í töflu 2, hægt er að hafna pví að tilviljun útskýri óvenjulega ávöxtun fyrir og eftir viðkomandi tímamót í sex tilfellum af átta miðað við 99\% öryggismörk. Undantekningarnar eru fyrsti viðskiptadagur eftir áramót og síðasti dagur fyrir pau mánaðamót sem ekki eru einnig ársfjórðungamót.

Á myndum 1 og 2 má sjá mun á dreifingu ávöxtunar úrvalsvísitölunnar árin 2000 til 2006, daginn fyrir og eftir ársfjórðungamót.

Dagarnir fyrir fyrrnefnd tímamót skera sig einnig úr hvað veltu varðar. Síðasta viðskiptadag mánaðarins er velta um $77 \%$ meiri að jafnaði en alla daga og síðasta dag ársfjórðungs 235\% meiri. ${ }^{18}$ Dagurinn eftir tímamót var rólegri og skar sig ekki úr frá öðrum dögum, veltan pó örlítið minni en á meðaldegi daginn eftir venjuleg mánaðamót eða ársfjórðungamót en aðeins meiri en á venjulegum degi fyrsta viðskiptadag ársins.

\footnotetext{
${ }^{18}$ Veltutölur voru reiknaðar fyrir tímabilið frá áramótum 1999-2000 og til 15. nóvember 2006. Par sem velta hefur farið ört vaxandi petta tímabil var velta hvers dags fyrst umreiknuð yfir í hlutfall af veltu síðustu 100 viðskiptadaga og síðan athugað hver meðalveltan var eftir pví hvort um síðasta eða fyrsta viðskiptadag tímabils var að ræða eða ekki.
} 
Mynd 1. Ávöxtun við ársfjórðungamót 2000-2006.

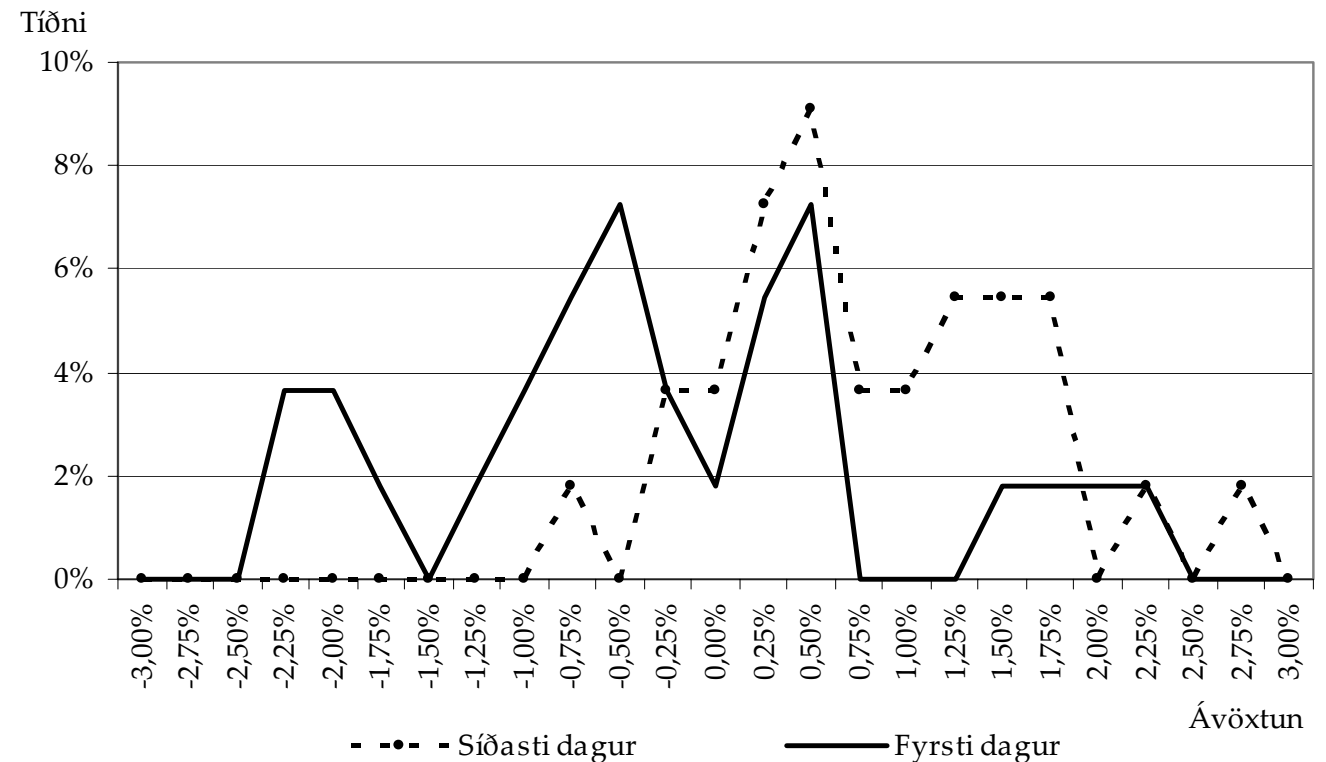

Mynd 2. Ávöxtun við ársfjórðungamót 2000-2006, péttifall.

Ávöxtun

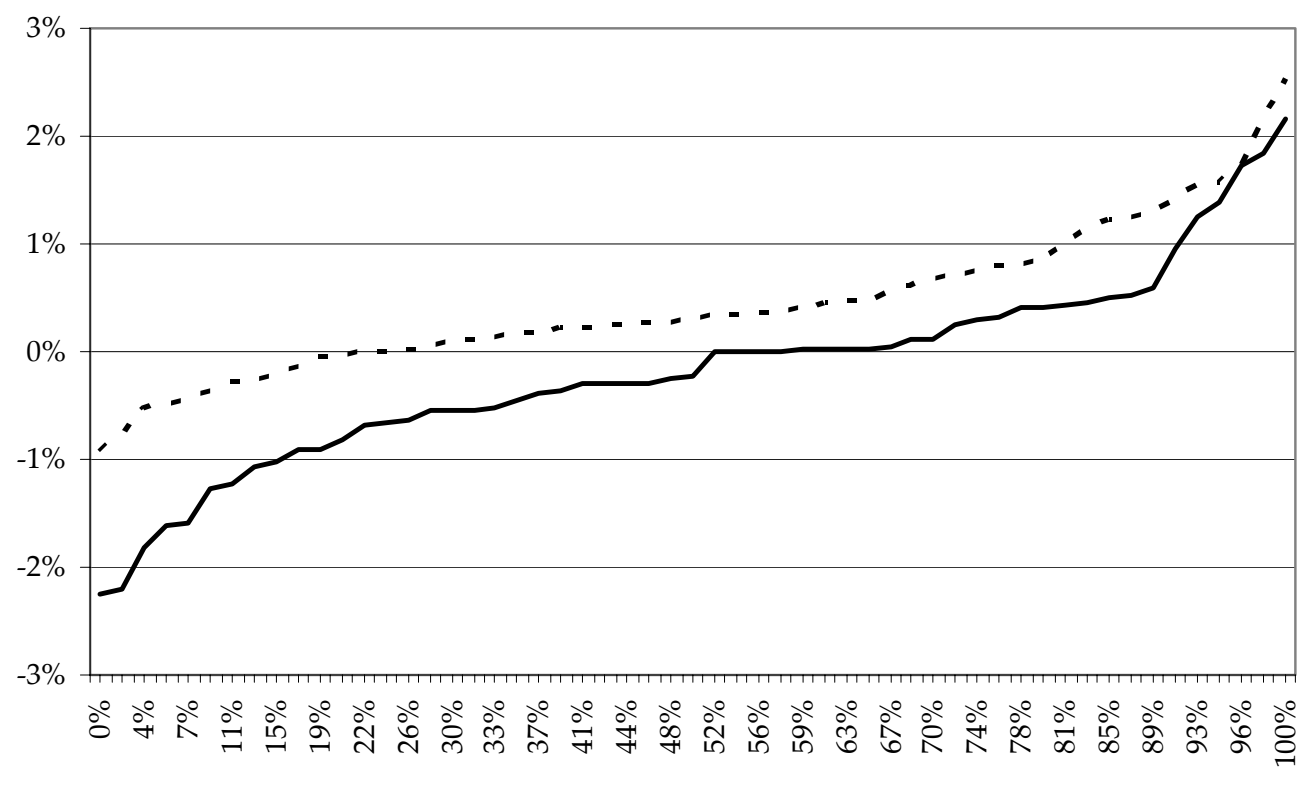

- - - Síðasti dagur ársfjórðungs ——Fyrsti dagur ársfjórðungs

Í töflum 4 til 6 (aftast) má sjá ávöxtun hlutabréfa einstakra fyrirtækja um sömu tímamót og í töflu 7 (aftast) má sjá til samanburðar meðaltöl fyrir alla daga. Miðað er við öll fyrirtæki sem voru skráð í Kauphöllina í upphafi árs 2006 eða fengu skráningu 
á pví ári. ${ }^{19}$ Athygli er vakin á pví að meðaltölin eru ekki fyllilega sambærileg vegna pess hve mislengi fyrirtækin hafa verið skráð í Kauphöllina. Pá er rétt að hafa í huga að sum fyrirtækin hafa mjög stutta sögu sem skráð fyrirtæki í núverandi mynd, í tveimur tilfellum (Teymi og 365) einungis rétt rúman mánuð.

Í töflum 4 til 6 má sjá að frávik í ávöxtun úrvalsvísitölunnar um fyrrgreind tímamót er ekki hægt að rekja til viðskipta með fá fyrirtæki pví að svipað mynstur lýsir einnig verðpróun einstakra fyrirtækja í talsverðum meiri hluta tilfella. ${ }^{20}$ Pannig sést t.d. að nær prefalt fleiri fyrirtæki lækka í verði daginn eftir (21) áramót en daginn fyrir (8). Hlutfall peirra sem hækka er öfugt, nær prefalt fleiri hækka daginn fyrir áramót (29) en daginn eftir (11). Séu ársfjórðungamót skoðuð er munurinn enn frekar sláandi. Einungis 5 fyrirtæki hafa að meðaltali lækkað síðasta viðskiptadag fyrir ársfjórðungamót en 33 hækkað. Hins vegar hefur 31 fyrirtæki lækkað að meðaltali fyrsta viðskiptadag eftir ársfjórðungamót en einungis 8 hækkað.

Ekki virðist neinn augljós munur á verðpróun um mánaðamót eftir pví hvort fyrirtæki eru í úrvalsvísitölunni eða ekki, prátt fyrir að ætla megi að verðmyndun peirra sem eru í vísitölunni sé skilvirkari en annarra að jafnaði. ${ }^{21}$ Ef skoðuð eru pau fyrirtæki sem eru í vísitölunni í ársbyrjun 2007 kemur t.d. í ljós að 14 peirra hafa að meðaltali hækkað í verði síðasta viðskiptadag fyrir ársfjórðungamót en einungis eitt lækkað. ${ }^{22}$ Fyrsta dag eftir ársfjórðungamót hafa hins vegar 13 peirra lækkað að meðaltali en 2 hækkað. Sama niðurstaða fæst ef tölur um ávöxtun heildarvísitölu aðallista og úrvalsvísitölu eru bornar saman í töflu 1. Vísitölurnar virðast haga sér mjög svipað um mánaðamót, ársfjórðungamót og áramót, pótt samsetning peirra sé nokkuð mismunandi.

\section{6. Ávöxtun erlendra hlutabréfa um mánaðamót}

Til að fá samanburð við íslensku sérkennin sem lýst er að framan var ávöxtun 28 erlendra hlutabréfavísitalna skoðuð fyrir sama tímabil og einkum er horft til hér að framan, p.e. frá áramótum 1999-2000 og fram yfir áramót 2006-2007. 24 af pessum vísitölum eru fengnar af vef Yahoo-Finance og eiga að mati stjórnenda vefsins að gefa mynd af próun markaða í helstu kauphöllum heims. Við petta var bætt fjórum vísitölum frá nágrannalöndum okkar, Eistlandi, Svípjóð, Lettlandi og Litháen. Petta var gert til að hægt væri að skoða hvort pau sérkenni sem lýst er að framan fyrir

\footnotetext{
${ }^{19}$ Fyrirtækjum sem voru skráð hluta tímans en voru afskráð fyrir upphaf árs 2006 er sleppt og er úrtakið pví ekki dæmigert heldur skekkt (survivorship bias).

20 Í töflum 4 til 6 eru tölur fyrir öll skráð fyrirtæki, par á meðal pau sem ekki eru eða hafa verið í úrvalsvísitölunni.

21 Við val félaga í vísitöluna er litið til kauphallarviðskipta á 12 mánaða tímabili og markaðsvirðis í lok tímabilsins. Pessi fyrirtæki eru pví alla jafna með meira markaðsvirði en önnur félög og meiri viðskipti með bréf peirra.

22 Í pessum útreikningum eru ávöxtunartölur fyrir Dagsbrún notaðar til að skoða sögulega ávöxtun 365 en síðarnefnda félagið varð til pegar Dagsbrún var skipt upp í annars vegar Teymi og hins vegar 365 seint á árinu 2006.
} 
ávöxtun íslenskra hlutabréfa kæmu einnig fram í öðrum kauphöllum á sama svæði, sem eru auk pess reknar innan sömu samstæðu, OMX Group..$^{23}$

Helstu niðurstöður eru birtar í töflum 8 og 9 (aftast). Eins og sjá má á töflunum fer pví fjarri að sama mynstur einkenni pessa markaði og pann íslenska um mánaðamót, ársfjórðungamót eða áramót. Ávöxtun er í flestum tilfellum að jafnaði jákvæð bæði síðasta viðskiptadag fyrir og eftir slík tímamót. Ef eitthvað er virðist hún betri fyrsta viðskiptadag eftir pau tímamót sem skoðuð eru en pann síðasta fyrir pau. Baltnesku kauphallirnar og sú sænska skera sig ekki sérstaklega úr hvað petta varðar.

Раð er hins vegar athyglisvert hve góð ávöxtun erlendu vísitalnanna er í flestum tilfellum, bæði fyrir og eftir pau tímamót sem skoðuð eru. Раð er vísbending um að pau sérkenni í ávöxtun að hún sé áberandi mest rétt um og eftir mánaðamót, sem vísað var til í 2. kafla, séu enn til staðar á fjölmörgum mörkuðum.

Vegna pessa var sérstaklega skoðað hver meðalávöxtun á pessum mörkuðum hafi verið síðasta viðskiptadag og fyrstu prjá í hverjum mánuði og reiknað út hve stór hluti heildarávöxtunar kemur par fram, líkt og Kunkel, Compton og Beyer (2003) og ýmsir fleiri hafa gert. Sömu útreikningar voru einnig gerðir fyrir íslensku úrvalsvísitöluna. Sérstaklega var skoðað hve stór hluti heildarávöxtunar á pessum mörkuðum hefur fallið til pessa fjóra viðskiptadaga að jafnaði. Niðurstöðurnar eru birtar í töflu 10 (aftast).

Eins og sjá má í töflu 10 lifir petta sérkenni í ávöxtun góðu lífi. Á einungis 5 af peim 29 mörkuðum sem til skoðunar eru fellur um pað bil helmingur eða meira af allri ávöxtun ekki til pessa fjóra daga, sem pó eru ekki nema rétt tæpur fimmtungur allra viðskiptadaga á flestum mörkuðum. ${ }^{24}$ Eins og sjá má í töflunni skipta síðasti viðskiptadagur og sá fyrsti í hverjum mánuði hér langmestu, annar og priðji viðskiptadagur hvers mánaðar vega ekki jafnpungt. Á rétt rúmum helmingi markaðanna er ávöxtun pessa fjóra daga meiri en alla daga samanlagt. Aðra daga er hún pví neikvæð að jafnaði á peim mörkuðum.

Sem fyrr segir hafa ekki fengist haldgóðar skýringar á pessum frávikum í ávöxtun um og rétt eftir mánaðamót, pótt ýmsar tilgátur hafi verið settar fram. Hér verður ekki gerð tilraun til að skýra frávikin enda væri pað efni í sjálfstæða grein.

Íslenski markaðurinn er ein af undantekningunum. Hér var ávöxtun fyrrnefndra fjögurra daga að jafnaði örlítið neikvæð, hin mikla hækkun sem varð að jafnaði fyrir mánaðamót gekk öll til baka og örlítið betur fyrstu tvo viðskiptadaga mánaðarins. Enginn hinna markaðanna sýnir sama mynstur og sá íslenski að pessu leyti.

\footnotetext{
${ }^{23}$ Kauphallirnar hafa ekki verið reknar af sömu samstæðu allan pann tíma sem hér er til skoðunar en höfðu einnig áður með sér náið samstarf. Íslenska kauphöllin varð ekki hluti af OMX Group fyrr en undir lok árs 2006. Úlf Níelsson (2007) hefur skoðað samspil kauphallanna á Norðurlöndum og í baltnesku löndunum. Niðurstaða hans var m.a. að lítil tengsl væru á milli verðsveiflna á milli landa á mörkuðunum .

${ }^{24}$ Í töflunni og í umfjölluninni hér er Hollandi sleppt vegna pess að meðalávöxtun allra daga var par neikvæð.
} 


\section{Sveiflur í verði eftir tíma dags}

Hátíðnigögnin fyrir úrvalsvísitöluna (án arðs), sem lýst var í 3. kafla, gera pað kleift að skoða á hvaða tíma dagsins verð á vísitölunni breytist. Pau gögn eru einungis til frá 16. febrúar 2004 og pví ekki fyrir allt pað tímabil sem hér hefur einkum verið skoðað.

Ákveðið var að skipta peim sex klukkustundum (frá 10 til 1625) sem markaðir eru opnir á hverjum viðskiptadegi niður í 12 hálftíma og skoða verðpróun innan hvers hálftíma. Pessi tímaeining var valin vegna pess að hún er algeng í sambærilegum erlendum rannsóknum og m.a. notuð í rannsókn Carharts o.fl. (2002) sem áður var vikið að.

Pegar gögnin eru skoðuð miðað við pá skiptingu blasir við að verulegur munur er á verðpróun bréfa að jafnaði eftir tíma dags. Bréf hækka fyrsta klukkutímann sem markaðurinn er opinn og síðan aftur síðasta hálftímann fyrir lokun en tímann par á milli breytist meðalverð nánast ekki neitt. Á mynd 3 má sjá meðalávöxtun úrvalsvísitölunnar eftir hálftímum frá og með 16. febrúar 2004 til og með 5. janúar 2007.

Munurinn á ávöxtun eftir tímabilum miðað við pessa skiptingu er vel tölfræðilega marktækur. Kruskal-Wallis próf gefur 0,0001\% líkur á pví að munurinn sé tilviljun.

Hér verður ekki reynt að finna réttar skýringar á pessu mynstri en pó má benda á að talsverð ávöxtun strax eftir opnun markaða getur endurspeglað fréttir sem fram hafa komið frá lokun markaða daginn áður. ${ }^{26}$ Ef góðar fréttir berast pegar markaðir eru lokaðir er við pví að búast að verð hækki strax eftir opnun. Sama skýring dugar augljóslega ekki til að útskýra mikla hækkun rétt fyrir lokun. ${ }^{27}$

\footnotetext{
${ }^{25}$ Síðasta gildi dagsins er oft skráð eftir kl. 16 vegna pess að dagslokauppboðið dregst aðeins fram yfir pann tíma.

${ }^{26}$ Pessi skýring er í anda peirrar hugsunar að ávöxtun bréfa falli til stöðugt en ekki einungis pegar markaðir eru opnir. Skv. pví ætti t.d. ávöxtun mánudaga að endurspegla priggja daga ávöxtun, p.e. pess dags og helgarinnar á undan. Um petta hefur verið deilt í fræðiritum en hér verður ekki reynt að leysa úr peirri deilu. Pó skal bent á að eins og fram kemur í næsta kafla skila mánudagar lélegri ávöxtun hérlendis. •að kemur illa heim og saman við kenninguna.

${ }^{27}$ Kauphöllin heldur sérstakt uppboð í lok dags sem kann að skýra að einhverju marki að verð breytist frekar á peim tíma en öðrum.
} 
Mynd 3. Ávöxtun eftir hálftímum 2004-2006.

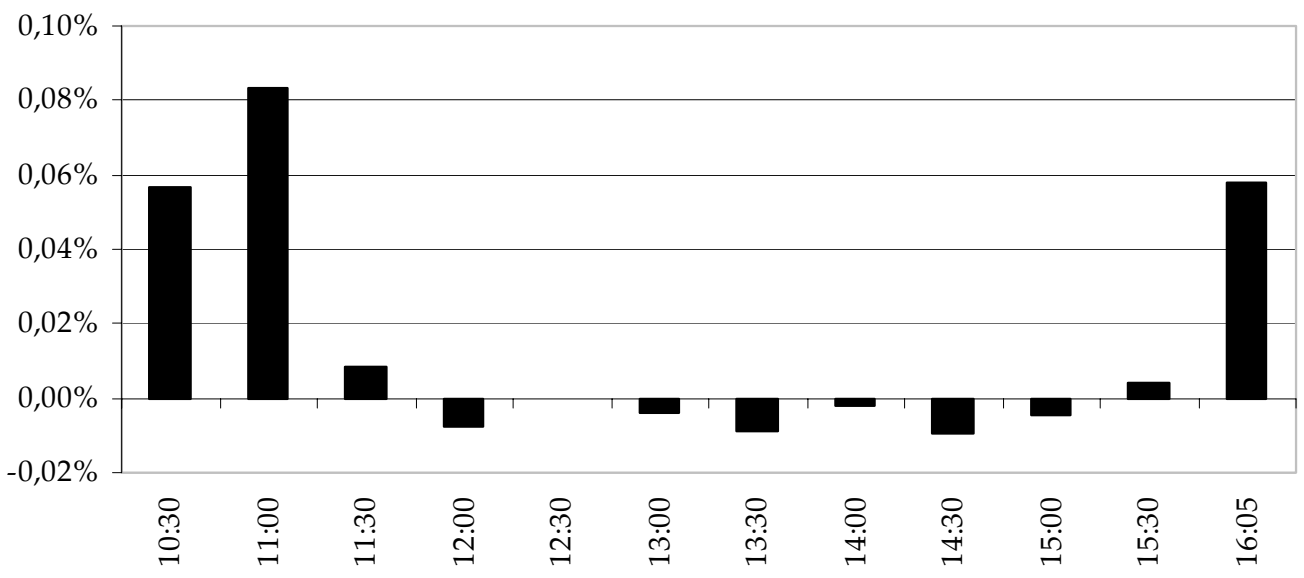

Ef skýringin á pví að ávöxtun markaða er óvenjugóð rétt fyrir lok uppgjörstímabila liggur í pví að markaðsaðilar sjá sér hag í að ýta verðinu upp væri við pví að búast að pað gerðist einkum skömmu fyrir lokun. Óvenjuhagstætt kauptilboð sem fram kemur að morgni ætti alla jafna ekki að hafa mikil áhrif á markaðsverð síðar um daginn og par með skráð dagslokaverð.

Pví var skoðað sérstaklega hvort verðpróun innan dags væri önnur síðasta dag fyrir eða eftir mánaðamót eða ársfjórðungamót en aðra daga. Rétt er að hafa í huga að par sem einungis eru til gögn fyrir tæp prjú ár eru mælingar ekki margar eða 35 mánaðamót og par af 12 ársfjórðungamót.

Niðurstaðan var engu að síður nokkuð skýr. Mikla ávöxtun rétt fyrir mánaðamót eða ársfjórðungamót virðist ekki mega rekja til hækkunar rétt fyrir lokun markaða viðkomandi dag. Hækkunin er langmest rétt eftir opnun markaða pessa daga. Skýringin á hækkuninni virðist pví ekki vera sú að markaðsaðilar freistist til að senda inn hagstæð kauptilboð rétt fyrir lokun. Á mynd 4 má sjá verðpróun eftir hálftímum, síðasta og fyrsta viðskiptadag ársfjórðungs. Til samanburðar eru einnig gildi fyrir meðaltöl allra daga. 
Mynd 4. Ávöxtun um ársfjórðungamót.

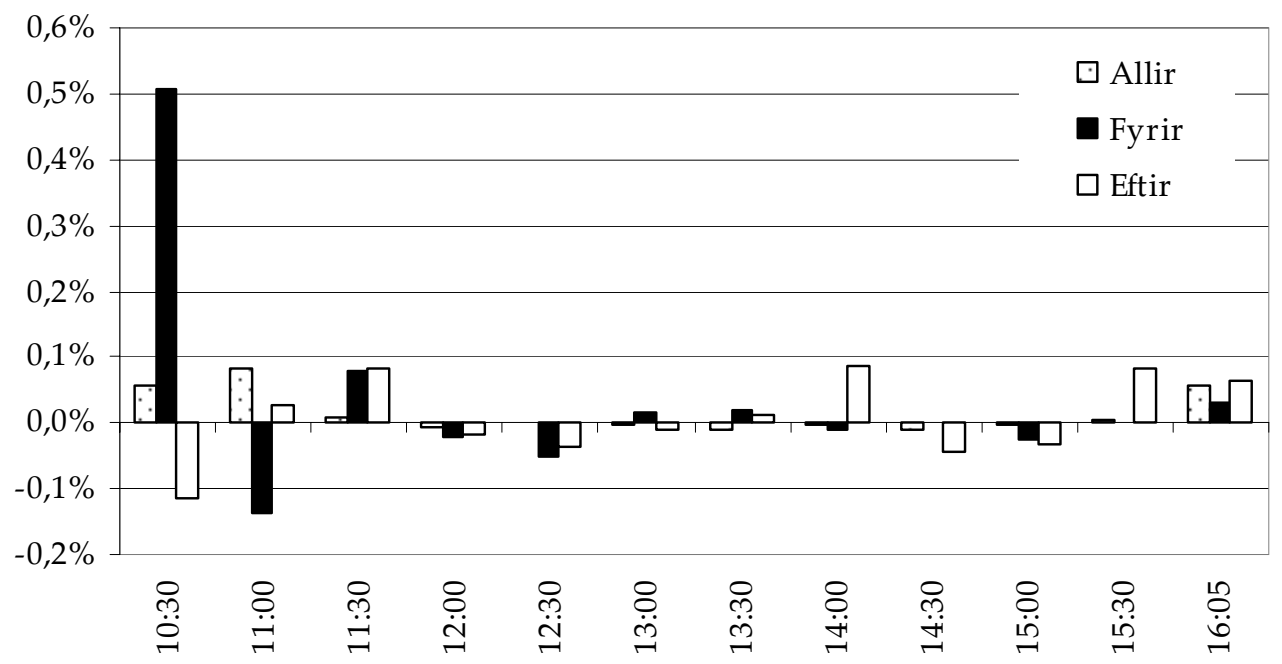

Sú mikla hækkun sem verður að meðaltali fyrsta hálftíma síðasta viðskiptadags hvers ársfjórðungs er tölfræðilega marktækt frábrugðin meðalhækkun á sama tíma alla daga miðað við 95\% öryggismörk. Mann-Whitney-Wilcoxon próf gefur 2,4\% líkur á pví að sá munur sem sést í gögnunum komi fram ef meðalávöxtun fyrsta hálftímans er sú sama alla daga.

Heldur léleg ávöxtun fyrsta dag eftir ársfjórðungamót virðist einkum koma fram fyrsta hálftímann eftir opnun. Pað frávik frá meðalávöxtun á sama tíma aðra daga er pó ekki tölfræðilega marktækt skv. Mann-Whitney-Wilcoxon prófi. Pað bendir pó til pess að verð hafi verið óeðlilega hátt í lok síðasta viðskiptadags ársfjórðungs að pað skuli lækka aftur strax og markaðir opna aftur á nýjum ársfjórðungi.

\section{8. Önnur athugunarefni}

Ein af hugsanlegum skýringum sem fram hefur komið á mikilli ávöxtun hlutabréfa erlendis um og upp úr mánaðamótum er sem fyrr segir að rekja megi hana til sveiflna í eftirspurn sem aftur megi rekja til greiðsluvenja sem leiði til sveiflna í lausu fé hjá hluta fjárfesta (Ogden 1990). Pessi kenning virðist ekki hafa náð mikilli útbreiðslu en engu að síður var skoðað hvort hún gæti staðist miðað við íslensk gögn.

Aðstæður hugsanlegra fjárfesta eru vitaskuld mismunandi um mánaðamót og pað liggur í hlutarins eðli að greiðsla til eins er jafnframt greiðsla frá öðrum. Pó ætti að vera óhætt að fullyrða að ef mikil spurn er eftir hlutabréfum síðasta dag mánaðarins vegna óvenjumikils lauss fjár pá en lítil næsta dag á eftir vegna lítils framboðs á fé pá ættu pess einnig að sjást merki í verði annarra fjárfestingarkosta sem keppa við hlutafé. ${ }^{28}$

\footnotetext{
28 Hér er rétt að hafa í huga að hlutabréfaviðskipti eru almennt gerð upp á íslenska markaðinum daginn eftir að til peirra er stofnað (t+1 kerfi). Рað pýðir t.d. að viðskipti síðasta viðskiptadag mánaðar eru gerð upp fyrsta viðskiptadag næsta mánaðar. Prátt fyrir petta parf kaupandi að hafa næga greiðslugetu á viðskiptadegi til að geta keypt.
} 
Í ljósi pessa voru vextir á millibankamarkaði skoðaðir til að sjá hvort pess væru einhver merki að sveiflur í lausu fé á markaðinum væru pannig um mánaðamót að pær gætu skýrt pær sveiflur sem sjást í hlutabréfaverði. Ákveðið var að skoða vexti til eins dags á millibankamarkaði, REIBOR-vexti. Til að leiðrétta fyrir sveiflum í almennu vaxtastigi var reiknaður munurinn á fyrrnefndum REIBOR-vöxtum annars vegar og á vöxtum á viðskiptareikningum innlánsstofnana í Seðlabanka hins vegar. Skoðað var sama tímabil og áður, p.e. 2000 til 2006.

Niðurstöðurnar gáfu sterklega til kynna að ekki væri hægt að leita skýringa á sveiflum í hlutabréfaverði fyrir og eftir mánaðamót í pví að sveiflur væru í lausu fé á peim tíma. Meðalvaxtamunur alla daga, skv. fyrrgreindri skilgreiningu, reyndist 3,01 prósentustig. Um mánaðamót var hann hins vegar nokkru meiri eða 3,87 prósentustig síðasta viðskiptadag hvers mánaðar. Fyrstu tvo viðskiptadaga hvers mánaðar var hann minni en petta en pó meiri en alla daga að jafnaði eða annars vegar 3,11 og hins vegar 3,05 prósentustig. Hátt vaxtastig síðasta viðskiptadag hvers mánaðar ætti ef eitthvað er að draga aðeins niður hlutabréfaverð. Pví virðist skýringa á hækkun fyrir mánaðamót en lækkun á eftir ekki að vera að leita í sveiflum í lausu fé á peim tíma.

Áður hefur verið bent á að ávöxtun íslenskra hlutabréfa er nokkuð mismunandi eftir vikudögum (Stefán B. Gunnlaugsson, 2003, Frosti Ólafsson, 2006, og Kauphöll Íslands, 2006). Nánar tiltekið hefur hún reynst aðeins meiri síðari hluta vikunnar en fyrstu daga hennar. Par sem markaðir loka um helgar er talsvert líklegra að fyrsti viðskiptadagur hvers mánaðar sé mánudagur en annar vikudagur. Af sömu ástæðu er líklegra að síðasti viðskiptadagur lendi á föstudegi en öðrum degi. Pví er líklegt að almenn tilhneiging markaðarins til að skila góðri ávöxtun síðasta viðskiptadag hvers mánaðar hafi pau áhrif að ávöxtun föstudaga sé meiri en annarra daga. Af hliðstæðri ástæðu gæti pað dregið niður ávöxtun mánudaga að peir eru líklegastir allra daga til að vera fyrsti viðskiptadagur hvers mánaðar.

Pví var skoðað hvort mismunur í ávöxtun eftir vikudögum kæmi einnig fram ef peim dögum sem eru annaðhvort fyrsti eða síðasti viðskiptadagur mánaðar er sleppt. Niðurstaðan var eins og við var búist, munurinn á meðalávöxtun vikudaga minnkaði pegar mánaðamótum var sleppt. Eftir sem áđur var pó ávöxtun betri síðari hluta vikunnar en pann fyrri. Niðurstöðurnar má sjá í töflu 11.

Tafla 11. Ávöxtun úrvalsvísitölu með arði eftir vikudögum (2000-2006).

\begin{tabular}{lcc}
\hline & Meðalávöxtun & $\begin{array}{c}\text { Meðalávöxtun } \\
\text { án mánaðamóta }\end{array}$ \\
\hline Mánudagur & $-0,01 \%$ & $0,06 \%$ \\
Priðjudagur & $-0,01 \%$ & $0,00 \%$ \\
Miðvikudagur & $0,02 \%$ & $0,04 \%$ \\
Fimmtudagur & $0,20 \%$ & $0,19 \%$ \\
Föstudagur & $0,24 \%$ & $0,23 \%$ \\
\hline
\end{tabular}




\section{9. Ályktanir og lokaorð}

Enginn vafi leikur á pví að mánaðamót, og pó sérstaklega ársfjórðunga- eða áramót, eru óvenjulegur tími á íslenskum hlutabréfamarkaði. Verðpróun á pessum tímamótum er verulega frábrugðin pví sem almennt gerist á markaðinum og velta mun meiri en venjulega síðasta viðskiptadag hvers tímabils. Pessi munur er skýr pegar tímabilið frá árslokum 1999 er skoðað en hann virðist ekki hafa verið til staðar á fyrstu árum markaðarins.

Ekki liggur fyrir hver skýring pessa er. Раð að mikil hækkun fyrir ársfjórðungamót skuli koma fram að morgni síðasta viðskiptadags bendir ekki sérstaklega til pess að einhverjir séu vísvitandi að reyna að ýta dagslokaverði upp. Við slíkum viðskiptum væri einkum að búast síðari hluta dags, jafnvel rétt fyrir lokun. Hér er pó rétt að hafa í huga að eftirlitsaðilar fylgjast sérstaklega með viðskiptum rétt fyrir lokun sem gæti valdið pví að viðskipti sem tengjast markaðsmisnotkun komi fram fyrr. Um pað verður pó ekki fullyrt út frá peim gögnum sem hér hafa verið til skoðunar.

Skýringa á pessum frávikum í verði gæti einnig verið að leita í tilhneigingu einhverra markaðsaðila til að auka vægi hlutabréfa í eignasöfnum sínum rétt fyrir mánaðamót og pó sérstaklega ársfjórðunga- eða áramót. Раð gæti kallað fram verðbreytingar líkar peim sem sjást í gögnunum og pað kemur einnig vel heim og saman við óvenjumikla veltu pessa daga. Par sem gögnin sem pessi rannsókn byggist á sýna ekki hverjir eru á bak við pau kauptilboð sem ýtt hafa upp verði er ekki hægt að skera úr um hvort svo sé. 


\section{Heimildir}

Allen, Linda og Anthony Saunders. (1992). Bank window dressing: Theory and evidence. Journal of Banking and Finance, 16, 585-623.

Ariel, Robert A. (1987). A monthly effect in stock returns. Journal of Financial Economics, 18, 161-174.

Banz, Rolf. (1981). The Relationship between Return and Market Value of Common Stocks. Journal of Financial Economics, 9, 3-18.

Carhart, Mark M., Ron Kaniel, David K. Musto og Adam V. Reed. (2002). Leaning for the Tape: Evidence of Gaming Behavior in Equity Mutual Funds. The Journal of Finance, 57, 661-693.

Fjármálaeftirlitið. (2006). Fréttatilkynning Fjármálaeftirlitsins vegna könnunar á viðskiptum með skuldabréf Íbúðalánasjóðs. Höfundur ótilgreindur. 19. janúar.

Frosti Ólafsson. (2006). Almanaksáhrif á íslenskum hlutabréfamarkaði. Óbirt B.S.-ritgerð í hagfræði. Háskóli Íslands.

Griffiths, Mark D. og Drew B. Winters. (2005). The Turn of the Year in Money Markets: Tests of the Risk-Shifting, Window Dressing and Preferred Habitat Hypotheses. Journal of Business, 78, 1337-1363.

Jóhannes Sigurðsson. (2006). Dómar í verðbréfamarkaðsrétti 1980 til 2005. Rannsóknarstofnun í fjármálarétti við Háskólann í Reykjavík.

Kauphöll Íslands. (2006). Hvenær hækkar Úrvalsvísitalan? Höfundur ótilgreindur. Kauphallartídindi, 6. september, 17. tbl. 6. árg.

Keim, Donald B. (1983). Size Related Anomalies and Stock Return Seasonality: Further Empirical Evidence. Journal of Financial Economics, 12, 13-32.

Kunkel, Robert A., William S. Compton og Scott Beyer. (2003). The turn-of-the-month effect still lives: the international evidence. International Review of Financial Analysis, $12,207-221$.

Lakonishok, Josef og Seymour Smidt. (1988). Are Seasonal Anomalies Real? A Ninety-Year Perspective. The Review of Financial Studies, 1, 403-425.

Lög um verðbréfaviðskipti, nr. 33/2003.

Lee, Cheng-few, David C. Porter og Daniel G. Weaver. (1998). Indirect tests of the Haugen-Lakonishok small-firm/January effect hypotheses: window dressing versus performance hedging. The Financial Review, 33, 177-194.

Morey, Matthew R. og Edward S. Neal. (2006). Window dressing in bond mutual funds. The Journal of Financial Research, 39, 325-347.

Morgunblaðið. (2001). Gengi ÚA hinn 29. júní lækkað. Höfundur ótilgreindur. 17. júlí.

Morgunblaðið. (2004). Markaðsmisnotkun? Höfundur ótilgreindur. 29. janúar.

Ogden, Joseph P. (1990). Turn-of-Month Evaluations of Liquid Profits and Stock Returns: A Common Explanation for the Monthly and January Effects. The Journal of Finance, 45, 1259-1272. 
Poterba, James M. og Scott J. Weisbenner. (2002). Capital Gains Tax Rules, Tax-loss Trading and Turn-of-the-year Returns. The Journal of Finance, 56, 353-368.

Reikningsskilanefnd Félags löggiltra endurskoðenda. (1991). Um bókun hlutabréfa hjá verðbréfasjóðum. 28. janúar. Birt á vef félagsins www.fle.is.

Reikningsskilanefnd Félags löggiltra endurskoðenda. (1995). Mat á verðmæti hlutabréfa í uppgjörum hlutabréfasjóða og fjárfestingarfélaga. 1. janúar. Birt á vef félagsins www.fle.is.

Reikningsskilanefnd Félags löggiltra endurskoðenda. (1998). Markaðsverð hlutabréfa í reikningsskilum. 30. janúar. Birt á vef félagsins www.fle.is.

Reinganum, Marc R. (1983). The Anomalous Stock Market Behavior of Small Firms in January: Empirical Tests for Tax-Loss Effects. Journal of Financial Economics, 12, 12591272.

Stefán B. Gunnlaugsson. (2003). Er samband á milli daga, mánaða, hátíða og ávöxtunar á íslenskum hlutabréfamarkaði? Tímarit um viðskipti og efnahagsmál, 1, 7388.

Úlf Níelsson. (2007). Interdependence of Nordic and Baltic Stock Markets. Væntanlegt í Baltic Journal of Economics, febrúarhefti.

Vísbending. (2006). Er svindlað á hlutabréfamarkaði? Höfundur ótilgreindur. Vísbending, 29. september, 37. tbl. 24. árg. 
Tafla 1. Ávöxtun íslenskra hlutabréfavísitalna um mánaðamót, ársfjórðungamót og áramót

\begin{tabular}{|c|c|c|c|c|c|}
\hline \multirow{5}{*}{ ICEX-15TR } & \multirow{4}{*}{$\begin{array}{l}1993-2006 \\
1993-1999\end{array}$} & \multicolumn{2}{|c|}{ Mánaðamót } & \multicolumn{2}{|c|}{ Áramót } \\
\hline & & Fyrir & Eftir & Fyrir & Eftir \\
\hline & & $0,17 \%$ & $-0,19 \%$ & $0,59 \%$ & $-0,27 \%$ \\
\hline & & $-0,02 \%$ & $-0,07 \%$ & $0,30 \%$ & $-0,19 \%$ \\
\hline & $2000-2006$ & $0,35 \%$ & $-0,31 \%$ & $0,87 \%$ & $-0,31 \%$ \\
\hline \multirow[t]{3}{*}{ ICEX-15 } & 1993-2006 & $0,16 \%$ & $-0,20 \%$ & $0,59 \%$ & $-0,27 \%$ \\
\hline & 1993-1999 & $-0,02 \%$ & $-0,09 \%$ & $0,30 \%$ & $-0,19 \%$ \\
\hline & $2000-2006$ & $0,35 \%$ & $-0,31 \%$ & $0,87 \%$ & $-0,31 \%$ \\
\hline \multirow[t]{3}{*}{ ICEX-Main } & 1993-2006 & $0,21 \%$ & $-0,23 \%$ & $0,62 \%$ & $-0,29 \%$ \\
\hline & 1993-1999 & $0,02 \%$ & $-0,10 \%$ & $0,28 \%$ & $-0,15 \%$ \\
\hline & 2000-2006 & $0,39 \%$ & $-0,37 \%$ & $0,96 \%$ & $-0,38 \%$ \\
\hline
\end{tabular}

\begin{tabular}{|c|c|c|c|c|c|c|}
\hline \multirow{5}{*}{ ICEX-15TR } & \multirow{4}{*}{$\begin{array}{l}1993-2006 \\
1993-1999\end{array}$} & \multicolumn{2}{|c|}{$\begin{array}{l}\text { Ársfjórðunga- } \\
\text { mót }\end{array}$} & \multicolumn{2}{|c|}{$\begin{array}{c}\text { Mánaðamót, } \\
\text { ekki árs- } \\
\text { fjórðungamót }\end{array}$} & \multirow{3}{*}{$\begin{array}{c}\text { Allir } \\
\text { dagar } \\
0,094 \%\end{array}$} \\
\hline & & Fyrir & Eftir & Fyrir & Eftir & \\
\hline & & 0,38\% & $-0,25 \%$ & $0,06 \%$ & $-0,16 \%$ & \\
\hline & & $0,05 \%$ & $-0,09 \%$ & $-0,06 \%$ & $-0,07 \%$ & $0,096 \%$ \\
\hline & $2000-2006$ & $0,71 \%$ & $-0,41 \%$ & $0,17 \%$ & $-0,25 \%$ & $0,091 \%$ \\
\hline \multirow[t]{3}{*}{ ICEX-15 } & 1993-2006 & $0,38 \%$ & $-0,26 \%$ & $0,06 \%$ & $-0,17 \%$ & $0,085 \%$ \\
\hline & 1993-1999 & $0,04 \%$ & $-0,09 \%$ & $-0,06 \%$ & $-0,08 \%$ & $0,087 \%$ \\
\hline & $2000-2006$ & $0,71 \%$ & $-0,41 \%$ & $0,17 \%$ & $-0,25 \%$ & $0,084 \%$ \\
\hline \multirow[t]{3}{*}{ ICEX-Main } & 1993-2006 & $0,37 \%$ & $-0,28 \%$ & $0,13 \%$ & $-0,21 \%$ & $0,080 \%$ \\
\hline & 1993-1999 & $0,03 \%$ & $-0,11 \%$ & $0,01 \%$ & $-0,09 \%$ & $0,078 \%$ \\
\hline & $2000-2006$ & $0,70 \%$ & $-0,44 \%$ & $0,24 \%$ & $-0,33 \%$ & $0,082 \%$ \\
\hline
\end{tabular}

Fyrir vísar til síðasta viðskiptadags fyrir viðkomandi tímamót, eftir til fyrsta viðskiptadags eftir tímamótin. ICEX-15 er einnig kölluð úrvalsvísitala og ICEX-Main heildarvísitala aðallista. TR táknar vísitölu með arði (total return). 
Tafla 4. Ávöxtun íslenskra hlutafélaga um áramót og ársfjórðungamót, frá upphafi skráningar hvers fyrirtækis.

\begin{tabular}{|l|ccc|ccc|}
\hline Auðkenni & \multicolumn{3}{|c|}{ Áramót } & \multicolumn{3}{|c|}{ Ársfjórðungamót } \\
365 & Fjöldi & Fyrir & Eftir & Fjöldi & Fyrir & Eftir \\
A & 1 & $-1,03 \%$ & $0,21 \%$ & 1 & $-1,03 \%$ & $0,21 \%$ \\
ACT & 10 & $1,31 \%$ & $-0,32 \%$ & 40 & $0,67 \%$ & $-0,05 \%$ \\
ATOR & 10 & $0,60 \%$ & $0,04 \%$ & 39 & $0,25 \%$ & $0,09 \%$ \\
AUBA & 7 & $0,64 \%$ & $-0,68 \%$ & 25 & $0,96 \%$ & $-0,01 \%$ \\
BAKK & 5 & $-0,75 \%$ & $-0,57 \%$ & 21 & $0,72 \%$ & $0,47 \%$ \\
BURD & 7 & $-0,10 \%$ & $-0,09 \%$ & 27 & $-0,09 \%$ & $-0,15 \%$ \\
DB & 12 & $0,62 \%$ & $-1,46 \%$ & 51 & $0,46 \%$ & $-0,49 \%$ \\
EXISTA & 5 & $3,38 \%$ & $-2,38 \%$ & 22 & $0,73 \%$ & $-0,09 \%$ \\
FIEY & 1 & $2,74 \%$ & $0,00 \%$ & 2 & $1,37 \%$ & $-0,86 \%$ \\
FL & 3 & $0,00 \%$ & $0,00 \%$ & 13 & $0,00 \%$ & $-2,56 \%$ \\
FLAGA & 14 & $0,15 \%$ & $-0,45 \%$ & 56 & $0,10 \%$ & $-0,45 \%$ \\
FMB & 4 & $-0,85 \%$ & $0,00 \%$ & 13 & $-0,07 \%$ & $-0,27 \%$ \\
FO-ATLA & 6 & $0,56 \%$ & $0,00 \%$ & 22 & $-0,18 \%$ & $0,06 \%$ \\
GLB & 2 & $0,46 \%$ & $0,06 \%$ & 7 & $0,55 \%$ & $0,23 \%$ \\
GRND & 14 & $0,53 \%$ & $-0,16 \%$ & 56 & $0,40 \%$ & $-0,36 \%$ \\
HAMP & 13 & $0,92 \%$ & $0,45 \%$ & 55 & $0,28 \%$ & $0,19 \%$ \\
HFEIM & 13 & $-0,29 \%$ & $0,16 \%$ & 54 & $0,31 \%$ & $-0,20 \%$ \\
HTOR & 1 & $0,62 \%$ & $-0,62 \%$ & 4 & $0,81 \%$ & $-0,73 \%$ \\
IG & 6 & $6,92 \%$ & $0,00 \%$ & 24 & $1,73 \%$ & $-0,18 \%$ \\
JRDB & 9 & $0,00 \%$ & $-0,74 \%$ & 36 & $0,10 \%$ & $-0,04 \%$ \\
KAUP & 13 & $1,44 \%$ & $0,14 \%$ & 52 & $0,95 \%$ & $0,40 \%$ \\
KOGN & 7 & $0,72 \%$ & $0,28 \%$ & 25 & $0,47 \%$ & $-0,15 \%$ \\
LAIS & 6 & $2,03 \%$ & $-4,66 \%$ & 24 & $0,60 \%$ & $-1,17 \%$ \\
LTSJ & 9 & $1,53 \%$ & $-0,75 \%$ & 33 & $1,12 \%$ & $-0,43 \%$ \\
MARL & 5 & $2,35 \%$ & $0,00 \%$ & 20 & $0,16 \%$ & $-0,69 \%$ \\
MOSAIC & 14 & $-0,19 \%$ & $-0,26 \%$ & 56 & $0,51 \%$ & $-0,08 \%$ \\
NYHR & 2 & $-0,82 \%$ & $0,14 \%$ & 7 & $0,16 \%$ & $-0,13 \%$ \\
OPKF & 10 & $1,42 \%$ & $-1,30 \%$ & 37 & $0,74 \%$ & $-1,08 \%$ \\
OSSR & 8 & $1,03 \%$ & $-2,00 \%$ & 30 & $0,76 \%$ & $-0,61 \%$ \\
SAMH & 8 & $-0,14 \%$ & $-0,56 \%$ & 29 & $0,46 \%$ & $-0,54 \%$ \\
SFS B & 8 & $0,94 \%$ & $0,05 \%$ & 33 & $0,55 \%$ & $-0,39 \%$ \\
SIMI & 11 & $0,02 \%$ & $-2,07 \%$ & 43 & $0,64 \%$ & $-0,45 \%$ \\
STRB & 4 & $0,54 \%$ & $-3,00 \%$ & 16 & $0,04 \%$ & $-0,44 \%$ \\
TEYMI & 7 & $1,07 \%$ & $0,25 \%$ & 25 & $0,55 \%$ & $-0,02 \%$ \\
TF & 1 & $1,69 \%$ & $3,51 \%$ & 1 & $1,69 \%$ & $3,51 \%$ \\
TM & 2 & $0,00 \%$ & $0,00 \%$ & 11 & $0,00 \%$ & $0,00 \%$ \\
TNGI & 9 & $1,77 \%$ & $-0,36 \%$ & 33 & $1,21 \%$ & $-0,01 \%$ \\
TRS & 7 & $0,00 \%$ & $0,00 \%$ & 26 & $0,22 \%$ & $-0,04 \%$ \\
VNST & 12 & $2,75 \%$ & $-0,48 \%$ & 50 & $-0,01 \%$ & $-0,03 \%$ \\
\hline Neikvæð & 12 & $0,60 \%$ & $-0,02 \%$ & 48 & $0,06 \%$ & $-0,05 \%$ \\
Jákvæð & & 8 & 21 & & 5 & 31 \\
Núll & & 29 & 11 & & 33 & 8 \\
\hline & & & 8 & & 2 & 1 \\
\hline
\end{tabular}

Fyrir vísar til síðasta viðskiptadags fyrir viðkomandi tímamót, eftir til fyrsta viðskiptadags eftir tímamótin. 
Tafla 5. Ávöxtun íslenskra hlutafélaga um mánaðamót og ársfjórðungamót sem ekki eru áramót, frá upphafi skráningar hvers fyrirtækis.

\begin{tabular}{|l|ccc|ccc|}
\hline Auðkenni & \multicolumn{3}{|c|}{ Mánaðamót } & \multicolumn{3}{|c|}{ Ársfjórðungamót, ekki áramót } \\
& Fjöldi & Fyrir & Eftir & Fjöldi & Fyrir & Eftir \\
365 & 2 & $-1,23 \%$ & $2,87 \%$ & 0 & & \\
A & 118 & $-0,11 \%$ & $-0,11 \%$ & 30 & $0,45 \%$ & $0,04 \%$ \\
ACT & 115 & $0,33 \%$ & $-0,06 \%$ & 29 & $0,12 \%$ & $0,10 \%$ \\
ATOR & 75 & $0,67 \%$ & $0,00 \%$ & 18 & $1,09 \%$ & $0,25 \%$ \\
AUBA & 61 & $0,39 \%$ & $-0,08 \%$ & 16 & $1,18 \%$ & $0,80 \%$ \\
BAKK & 80 & $0,06 \%$ & $-0,12 \%$ & 20 & $-0,09 \%$ & $-0,17 \%$ \\
BURD & 153 & $0,31 \%$ & $-0,25 \%$ & 39 & $0,42 \%$ & $-0,16 \%$ \\
DB & 65 & $0,59 \%$ & $-0,02 \%$ & 17 & $-0,04 \%$ & $0,58 \%$ \\
EXISTA & 4 & $0,80 \%$ & $-0,31 \%$ & 1 & $0,00 \%$ & $-1,72 \%$ \\
FIEY & 37 & $0,00 \%$ & $-0,85 \%$ & 10 & $0,00 \%$ & $-3,42 \%$ \\
FL & 168 & $-0,02 \%$ & $-0,30 \%$ & 42 & $0,08 \%$ & $-0,46 \%$ \\
FLAGA & 38 & $-0,02 \%$ & $-0,04 \%$ & 9 & $0,28 \%$ & $-0,39 \%$ \\
FMB & 68 & $0,10 \%$ & $-0,01 \%$ & 16 & $-0,46 \%$ & $0,08 \%$ \\
FO-ATLA & 19 & $0,47 \%$ & $0,12 \%$ & 5 & $0,58 \%$ & $0,30 \%$ \\
GLB & 167 & $0,23 \%$ & $-0,20 \%$ & 42 & $0,36 \%$ & $-0,43 \%$ \\
GRND & 165 & $0,18 \%$ & $0,00 \%$ & 42 & $0,08 \%$ & $0,11 \%$ \\
HAMP & 161 & $0,44 \%$ & $0,02 \%$ & 41 & $0,51 \%$ & $-0,32 \%$ \\
HFEIM & 12 & $0,05 \%$ & $-0,28 \%$ & 3 & $0,87 \%$ & $-0,77 \%$ \\
HTOR & 74 & $0,39 \%$ & $-0,23 \%$ & 18 & $0,00 \%$ & $-0,24 \%$ \\
IG & 107 & $0,07 \%$ & $0,10 \%$ & 27 & $0,13 \%$ & $0,20 \%$ \\
JRDB & 155 & $0,42 \%$ & $0,11 \%$ & 39 & $0,79 \%$ & $0,49 \%$ \\
KAUP & 75 & $0,27 \%$ & $-0,26 \%$ & 18 & $0,38 \%$ & $-0,32 \%$ \\
KOGN & 72 & $0,42 \%$ & $-0,52 \%$ & 18 & $0,12 \%$ & $0,00 \%$ \\
LAIS & 97 & $0,57 \%$ & $-0,24 \%$ & 24 & $0,97 \%$ & $-0,31 \%$ \\
LTSJ & 58 & $0,23 \%$ & $0,94 \%$ & 15 & $-0,57 \%$ & $-0,94 \%$ \\
MARL & 168 & $0,11 \%$ & $-0,13 \%$ & 42 & $0,75 \%$ & $-0,02 \%$ \\
MOSAIC & 19 & $0,00 \%$ & $-0,11 \%$ & 5 & $0,55 \%$ & $-0,25 \%$ \\
NYHR & 110 & $0,53 \%$ & $-0,63 \%$ & 27 & $0,49 \%$ & $-1,00 \%$ \\
OPKF & 90 & $0,87 \%$ & $-0,19 \%$ & 22 & $0,66 \%$ & $-0,10 \%$ \\
OSSR & 87 & $0,38 \%$ & $-0,54 \%$ & 21 & $0,68 \%$ & $-0,53 \%$ \\
SAMH & 97 & $0,15 \%$ & $-0,26 \%$ & 25 & $0,42 \%$ & $-0,53 \%$ \\
SFS B & 128 & $0,34 \%$ & $-0,47 \%$ & 32 & $0,86 \%$ & $0,10 \%$ \\
SIMI & 48 & $0,50 \%$ & $-0,38 \%$ & 12 & $-0,13 \%$ & $0,41 \%$ \\
STRB & 75 & $0,23 \%$ & $0,20 \%$ & 18 & $0,34 \%$ & $-0,12 \%$ \\
TEYMI & 2 & $0,14 \%$ & $2,82 \%$ & 0 & & \\
TF & 35 & $0,07 \%$ & $0,00 \%$ & 9 & $0,00 \%$ & $0,00 \%$ \\
TM & $0,56 \%$ & $0,11 \%$ & 24 & $1,01 \%$ & $0,12 \%$ \\
TNGI & & $-0,41 \%$ & $-0,24 \%$ & 19 & $0,30 \%$ & $-0,06 \%$ \\
TRS & $0,27 \%$ & $-0,22 \%$ & 38 & $-0,88 \%$ & $0,13 \%$ \\
VNST & $6,00 \%$ & 36 & $-0,12 \%$ & $-0,06 \%$ \\
\hline Neikvæð & 36 & 11 & & 7 & 23 \\
Jákvæð & & 1 & & 4 & 14 \\
Núll & & & & & 1 \\
\hline
\end{tabular}


Tafla 6. Ávöxtun íslenskra hlutafélaga um mánaðamót sem ekki eru ársfjórðungamót, frá upphafi skráningar hvers fyrirtækis.

\begin{tabular}{|l|ccc|}
\hline Auðkenni & \multicolumn{3}{|c}{ Mánaðamót, ekki ársfjórðungamót } \\
365 & Fjöldi & Fyrir & Eftir \\
A & 1 & $-1,43 \%$ & $5,52 \%$ \\
ACT & 78 & $-0,51 \%$ & $-0,14 \%$ \\
ATOR & 76 & $0,37 \%$ & $-0,13 \%$ \\
AUBA & 50 & $0,53 \%$ & $0,01 \%$ \\
BAKK & 40 & $0,22 \%$ & $-0,37 \%$ \\
BURD & 53 & $0,14 \%$ & $-0,10 \%$ \\
DB & 102 & $0,23 \%$ & $-0,13 \%$ \\
EXISTA & 43 & $0,52 \%$ & $0,02 \%$ \\
FIEY & 2 & $0,23 \%$ & $0,24 \%$ \\
FL & 24 & $0,00 \%$ & $0,00 \%$ \\
FLAGA & 112 & $-0,07 \%$ & $-0,22 \%$ \\
FMB & 25 & $0,00 \%$ & $0,08 \%$ \\
FO-ATLA & 46 & $0,23 \%$ & $-0,05 \%$ \\
GLB & 12 & $0,43 \%$ & $0,05 \%$ \\
GRND & 111 & $0,15 \%$ & $-0,12 \%$ \\
HAMP & 110 & $0,14 \%$ & $-0,09 \%$ \\
HFEIM & 107 & $0,50 \%$ & $0,13 \%$ \\
HTOR & 8 & $-0,33 \%$ & $-0,06 \%$ \\
IG & 50 & $-0,25 \%$ & $-0,25 \%$ \\
JRDB & 71 & $0,06 \%$ & $0,17 \%$ \\
KAUP & 103 & $0,15 \%$ & $-0,04 \%$ \\
KOGN & 50 & $0,17 \%$ & $-0,32 \%$ \\
LAIS & 48 & $0,32 \%$ & $-0,20 \%$ \\
LTSJ & 64 & $0,28 \%$ & $-0,14 \%$ \\
MARL & 38 & $0,27 \%$ & $1,76 \%$ \\
MOSAIC & 112 & $-0,09 \%$ & $-0,16 \%$ \\
NYHR & 12 & $-0,09 \%$ & $-0,10 \%$ \\
OPKF & 73 & $0,42 \%$ & $-0,41 \%$ \\
OSSR & 60 & $0,92 \%$ & $0,02 \%$ \\
SAMH & 58 & $0,34 \%$ & $-0,53 \%$ \\
SFS B & 64 & $-0,06 \%$ & $-0,19 \%$ \\
SIMI & 85 & $0,18 \%$ & $-0,48 \%$ \\
STRB & 32 & $0,72 \%$ & $-0,35 \%$ \\
TEYMI & 50 & $0,07 \%$ & $0,31 \%$ \\
TF & 1 & $-1,40 \%$ & $2,13 \%$ \\
TM & 24 & $0,10 \%$ & $0,00 \%$ \\
TNGI & 66 & $0,23 \%$ & $0,16 \%$ \\
TRS & 50 & $0,51 \%$ & $-0,34 \%$ \\
VNST & 100 & $-0,17 \%$ & $-0,31 \%$ \\
\hline Neikvæð & 96 & $0,37 \%$ & $0,02 \%$ \\
Jákvæð & & 10 & 24 \\
Núll & & 29 & 14 \\
\hline
\end{tabular}


Tafla 7. Ávöxtun íslenskra hlutafélaga alla daga (2000-2006).

\begin{tabular}{|l|cccccc|}
\hline Auðkenni & \multicolumn{6}{|c|}{ Allir dagar } \\
& Meðaltal & Fjöldi & Minna en 0 & Jafnt og 0 & Meira en 0 & Hlutfall 0 \\
365 & $0,54 \%$ & 32 & 12 & 4 & 16 & $12,5 \%$ \\
A & $0,01 \%$ & 1743 & 552 & 684 & 507 & $39,2 \%$ \\
ACT & $0,18 \%$ & 1743 & 634 & 366 & 743 & $21,0 \%$ \\
ATOR & $0,09 \%$ & 1536 & 378 & 778 & 380 & $50,7 \%$ \\
AUBA & $0,04 \%$ & 1255 & 127 & 1038 & 90 & $82,7 \%$ \\
BAKK & $0,16 \%$ & 1649 & 570 & 410 & 669 & $24,9 \%$ \\
BURD & $0,04 \%$ & 1425 & 542 & 350 & 533 & $24,6 \%$ \\
DB & $0,00 \%$ & 1350 & 527 & 338 & 485 & $25,0 \%$ \\
EXISTA & $0,10 \%$ & 78 & 29 & 18 & 31 & $23,1 \%$ \\
FIEY & $-0,05 \%$ & 754 & 7 & 740 & 7 & $98,1 \%$ \\
FL & $0,16 \%$ & 1743 & 576 & 525 & 642 & $30,1 \%$ \\
FLAGA & $-0,10 \%$ & 774 & 302 & 266 & 206 & $34,4 \%$ \\
FMB & $0,13 \%$ & 1389 & 42 & 1288 & 59 & $92,7 \%$ \\
FO-ATLA & $0,14 \%$ & 393 & 106 & 140 & 147 & $35,6 \%$ \\
GLB & $0,11 \%$ & 1743 & 646 & 404 & 693 & $23,2 \%$ \\
GRND & $0,06 \%$ & 1675 & 358 & 943 & 374 & $56,3 \%$ \\
HAMP & $0,05 \%$ & 1611 & 181 & 1249 & 181 & $77,5 \%$ \\
HFEIM & $-0,12 \%$ & 240 & 119 & 38 & 83 & $15,8 \%$ \\
HTOR & $0,05 \%$ & 1288 & 26 & 1234 & 28 & $95,8 \%$ \\
IG & $0,04 \%$ & 1743 & 345 & 1113 & 285 & $63,9 \%$ \\
JRDB & $0,11 \%$ & 1509 & 331 & 836 & 342 & $55,4 \%$ \\
KAUP & $0,14 \%$ & 1535 & 557 & 310 & 668 & $20,2 \%$ \\
KOGN & $0,06 \%$ & 1500 & 390 & 750 & 360 & $50,0 \%$ \\
LAIS & $0,13 \%$ & 1743 & 648 & 338 & 757 & $19,4 \%$ \\
LTSJ & $0,01 \%$ & 1176 & 177 & 838 & 161 & $71,3 \%$ \\
MARL & $0,06 \%$ & 1743 & 615 & 539 & 589 & $30,9 \%$ \\
MOSAIC & $0,02 \%$ & 390 & 159 & 111 & 120 & $28,5 \%$ \\
NYHR & $0,03 \%$ & 1743 & 288 & 1125 & 330 & $64,5 \%$ \\
OPKF & $0,04 \%$ & 1240 & 417 & 437 & 386 & $35,2 \%$ \\
OSSR & $0,08 \%$ & 1743 & 689 & 393 & 661 & $22,5 \%$ \\
SAMH & $0,04 \%$ & 1380 & 407 & 577 & 396 & $41,8 \%$ \\
SFS B & $0,06 \%$ & 1743 & 70 & 1601 & 72 & $91,9 \%$ \\
SIMI & $0,10 \%$ & 1002 & 108 & 768 & 126 & $76,6 \%$ \\
STRB & $0,13 \%$ & 1535 & 492 & 473 & 570 & $30,8 \%$ \\
TEYMI & $0,96 \%$ & 32 & 6 & 7 & 19 & $21,9 \%$ \\
TF & $-0,02 \%$ & 708 & 3 & 703 & 2 & $99,3 \%$ \\
TM & $0,10 \%$ & 1743 & 328 & 1044 & 371 & $59,9 \%$ \\
TNGI & $0,08 \%$ & 1243 & 74 & 1106 & 63 & $89,0 \%$ \\
TRS & $0,02 \%$ & 1360 & 185 & 1000 & 175 & $73,5 \%$ \\
VNST & $0,08 \%$ & 1743 & 129 & 1453 & 161 & $83,4 \%$ \\
\hline
\end{tabular}


Tafla 8. Ávöxtun erlendra hlutabréfavísitalna á tímamótum árin 2000 til 2006.

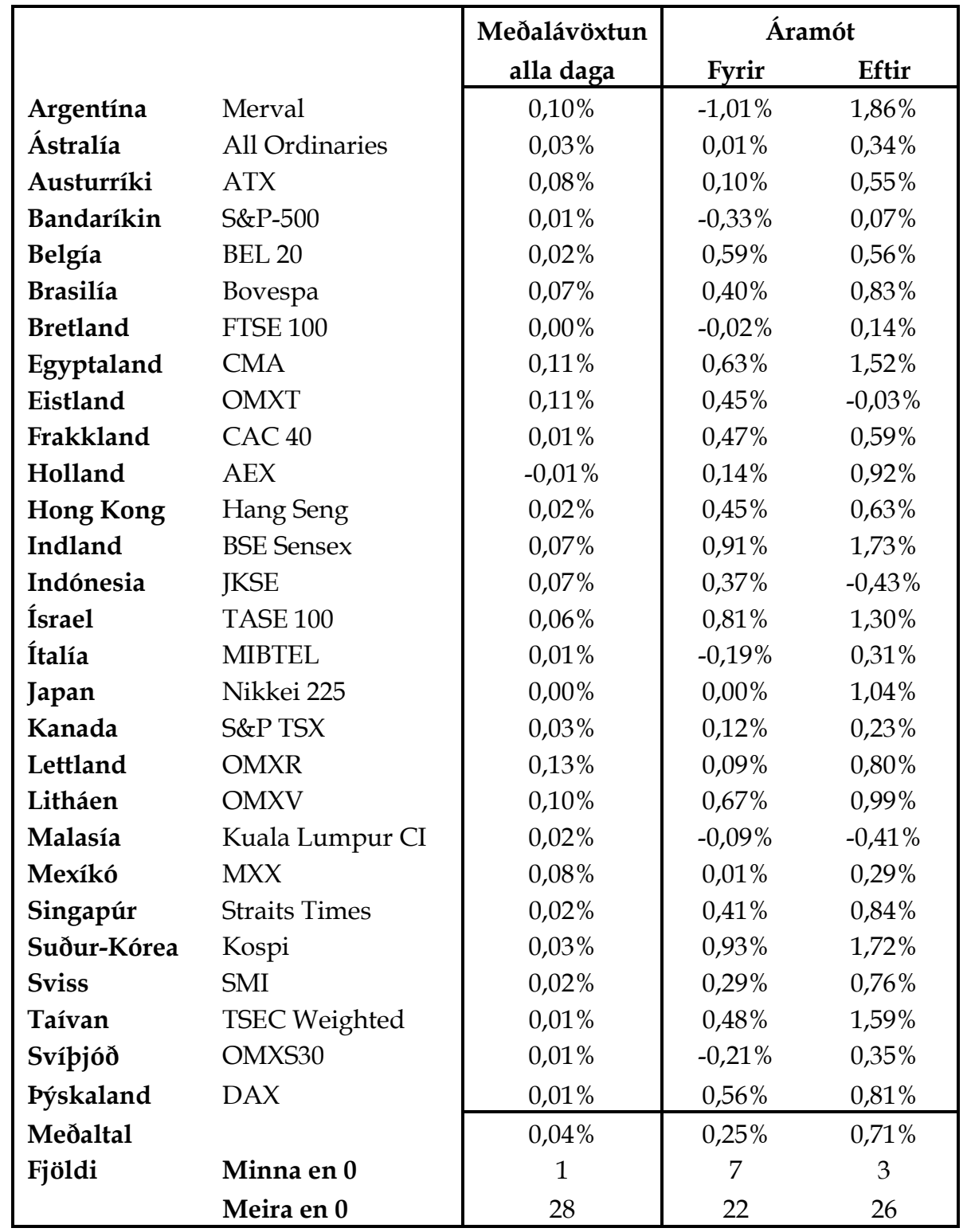


Tafla 9. Ávöxtun erlendra hlutabréfavísitalna á tímamótum árin 2000 til 2006 (framhald af töflu 8).

\begin{tabular}{|c|c|c|c|c|c|}
\hline \multirow[b]{3}{*}{ Argentína } & \multirow[b]{3}{*}{ Merval } & \multicolumn{2}{|c|}{ Ársfjórðungamót } & \multicolumn{2}{|c|}{ Mánaðamót } \\
\hline & & Fyrir & Eftir & Fyrir & Eftir \\
\hline & & $-0,07 \%$ & $0,94 \%$ & $0,00 \%$ & $0,74 \%$ \\
\hline Ástralía & All Ordinaries & $0,14 \%$ & $0,30 \%$ & $0,12 \%$ & $0,21 \%$ \\
\hline Austurríki & ATX & $0,35 \%$ & $0,41 \%$ & $0,08 \%$ & $0,54 \%$ \\
\hline Bandaríkin & S\&P-500 & $-0,17 \%$ & $0,30 \%$ & $0,07 \%$ & $0,28 \%$ \\
\hline Belgía & BEL 20 & $0,45 \%$ & $0,53 \%$ & $0,30 \%$ & $0,27 \%$ \\
\hline Brasilía & Bovespa & $0,39 \%$ & $0,86 \%$ & $0,32 \%$ & $0,63 \%$ \\
\hline Bretland & FTSE 100 & $-0,05 \%$ & $0,37 \%$ & $0,03 \%$ & $0,35 \%$ \\
\hline Egyptaland & CMA & $0,16 \%$ & $0,65 \%$ & $0,29 \%$ & $0,44 \%$ \\
\hline Eistland & OMXT & $0,40 \%$ & $0,08 \%$ & $0,15 \%$ & $0,21 \%$ \\
\hline Frakkland & CAC 40 & $0,01 \%$ & $0,38 \%$ & $0,23 \%$ & $0,27 \%$ \\
\hline Holland & AEX & $0,06 \%$ & $0,45 \%$ & $0,24 \%$ & $0,30 \%$ \\
\hline Hong Kong & Hang Seng & $0,39 \%$ & $0,21 \%$ & $0,24 \%$ & $0,29 \%$ \\
\hline Indland & BSE Sensex & $0,53 \%$ & $1,00 \%$ & $0,36 \%$ & $0,64 \%$ \\
\hline Indónesia & JKSE & $0,49 \%$ & $-0,18 \%$ & $0,23 \%$ & $-0,10 \%$ \\
\hline Ísrael & TASE 100 & $0,13 \%$ & $0,32 \%$ & $0,09 \%$ & $0,34 \%$ \\
\hline Ítalía & MIBTEL & $-0,19 \%$ & $0,41 \%$ & $0,05 \%$ & $0,26 \%$ \\
\hline Japan & Nikkei 225 & $0,07 \%$ & $0,63 \%$ & $0,05 \%$ & $0,49 \%$ \\
\hline Kanada & S\&P TSX & $0,34 \%$ & $0,31 \%$ & $0,30 \%$ & $0,40 \%$ \\
\hline Lettland & OMXR & $0,41 \%$ & $0,10 \%$ & $0,42 \%$ & $0,05 \%$ \\
\hline Litháen & OMXV & $0,40 \%$ & $0,36 \%$ & $0,21 \%$ & $0,26 \%$ \\
\hline Malasía & Kuala Lumpur CI & $0,00 \%$ & $-0,31 \%$ & $-0,03 \%$ & $-0,01 \%$ \\
\hline Mexíkó & $\mathrm{MXX}$ & $0,20 \%$ & $0,62 \%$ & $0,19 \%$ & $0,76 \%$ \\
\hline Singapúr & Straits Times & $0,35 \%$ & $0,21 \%$ & $0,21 \%$ & $0,30 \%$ \\
\hline Suður-Kórea & Kospi & $0,49 \%$ & $0,73 \%$ & $0,49 \%$ & $0,77 \%$ \\
\hline Sviss & SMI & $0,14 \%$ & $0,42 \%$ & $0,04 \%$ & $0,39 \%$ \\
\hline Taívan & TSEC Weighted & $0,38 \%$ & $0,18 \%$ & $0,28 \%$ & $0,00 \%$ \\
\hline Svípjód & OMXS30 & $-0,19 \%$ & $0,47 \%$ & $0,12 \%$ & $0,45 \%$ \\
\hline Pýskaland & DAX & $0,02 \%$ & $0,49 \%$ & $0,19 \%$ & $0,42 \%$ \\
\hline Meðaltal & & $0,20 \%$ & $0,40 \%$ & $0,19 \%$ & $0,36 \%$ \\
\hline Fjöldi & Minna en 0 & 6 & 2 & 2 & 3 \\
\hline & Meira en 0 & 23 & 27 & 27 & 26 \\
\hline
\end{tabular}


Tafla 10. Ávöxtun hlutabréfavísitalna um og eftir mánaðamót árin 2000 til 2006.

\begin{tabular}{|c|c|c|c|c|c|c|}
\hline & \multirow{2}{*}{$\begin{array}{c}\text { Meơalávöxtun } \\
\text { alla daga }\end{array}$} & \multicolumn{4}{|c|}{ Mánaðamót } & \multirow{2}{*}{$\begin{array}{c}\text { Hlutfall } \\
\text { heildar }\end{array}$} \\
\hline & & $t-1$ & $t+1$ & $t+2$ & $t+3$ & \\
\hline Argentína & $0,10 \%$ & $-0,00 \%$ & $0,74 \%$ & $0,08 \%$ & $0,22 \%$ & $49,9 \%$ \\
\hline Ástralía & $0,03 \%$ & $0,12 \%$ & $0,21 \%$ & $0,11 \%$ & $-0,02 \%$ & $60,2 \%$ \\
\hline Austurríki & $0,08 \%$ & $0,08 \%$ & $0,54 \%$ & $0,19 \%$ & $0,01 \%$ & $51,9 \%$ \\
\hline Bandaríkin & $0,01 \%$ & $0,07 \%$ & $0,28 \%$ & $-0,02 \%$ & $-0,03 \%$ & $244,2 \%$ \\
\hline Belgía & $0,02 \%$ & $0,30 \%$ & $0,27 \%$ & $0,08 \%$ & $0,02 \%$ & $139,4 \%$ \\
\hline Brasilía & $0,07 \%$ & $0,32 \%$ & $0,63 \%$ & $0,40 \%$ & $0,16 \%$ & $105,3 \%$ \\
\hline Bretland & $0,00 \%$ & $0,03 \%$ & $0,35 \%$ & $0,03 \%$ & $0,03 \%$ & $15139,1 \%$ \\
\hline Egyptaland & $0,11 \%$ & $0,29 \%$ & $0,44 \%$ & $0,19 \%$ & $0,27 \%$ & $67,6 \%$ \\
\hline Eistland & $0,11 \%$ & $0,15 \%$ & $0,21 \%$ & $0,16 \%$ & $-0,09 \%$ & $18,7 \%$ \\
\hline Frakkland & $0,01 \%$ & $0,23 \%$ & $0,27 \%$ & $-0,06 \%$ & $0,02 \%$ & $318,5 \%$ \\
\hline Holland & $-0,01 \%$ & $0,24 \%$ & $0,30 \%$ & $-0,04 \%$ & $-0,03 \%$ & \\
\hline Hong Kong & $0,02 \%$ & $0,24 \%$ & $0,29 \%$ & $0,33 \%$ & $-0,04 \%$ & $225,6 \%$ \\
\hline Indland & $0,07 \%$ & $0,36 \%$ & $0,64 \%$ & $0,26 \%$ & $0,18 \%$ & $101,3 \%$ \\
\hline Indónesia & $0,07 \%$ & $0,23 \%$ & $-0,10 \%$ & $0,42 \%$ & $0,20 \%$ & $50,3 \%$ \\
\hline Ísland & $0,09 \%$ & $0,35 \%$ & $-0,31 \%$ & $-0,14 \%$ & $0,07 \%$ & $-1,0 \%$ \\
\hline Ísrael & $0,06 \%$ & $0,09 \%$ & $0,34 \%$ & $0,22 \%$ & $0,11 \%$ & $81,2 \%$ \\
\hline Ítalía & $0,01 \%$ & $0,05 \%$ & $0,26 \%$ & $0,03 \%$ & $0,01 \%$ & $124,9 \%$ \\
\hline Japan & $0,00 \%$ & $0,05 \%$ & $0,49 \%$ & $0,33 \%$ & $-0,33 \%$ & $705,9 \%$ \\
\hline Kanada & $0,03 \%$ & $0,30 \%$ & $0,40 \%$ & $0,02 \%$ & $0,15 \%$ & $151,6 \%$ \\
\hline Lettland & $0,13 \%$ & $0,42 \%$ & $0,05 \%$ & $-0,26 \%$ & $-0,23 \%$ & $-0,9 \%$ \\
\hline Litháen & $0,10 \%$ & $0,21 \%$ & $0,26 \%$ & $-0,30 \%$ & $0,21 \%$ & $17,3 \%$ \\
\hline Malasía & $0,02 \%$ & $-0,03 \%$ & $-0,01 \%$ & $0,01 \%$ & $0,02 \%$ & $-3,7 \%$ \\
\hline Mexíkó & $0,08 \%$ & $0,19 \%$ & $0,76 \%$ & $0,34 \%$ & $0,01 \%$ & $74,9 \%$ \\
\hline Singapúr & $0,02 \%$ & $0,21 \%$ & $0,30 \%$ & $0,36 \%$ & $-0,00 \%$ & $254,1 \%$ \\
\hline Suður-Kórea & $0,03 \%$ & $0,49 \%$ & $0,77 \%$ & $0,17 \%$ & $0,06 \%$ & $211,4 \%$ \\
\hline Sviss & $0,02 \%$ & $0,04 \%$ & $0,39 \%$ & $0,06 \%$ & $0,05 \%$ & $157,5 \%$ \\
\hline Taívan & $0,01 \%$ & $0,28 \%$ & $-0,00 \%$ & $0,48 \%$ & $-0,04 \%$ & $445,2 \%$ \\
\hline Svípjód & $0,01 \%$ & $0,12 \%$ & $0,45 \%$ & $0,10 \%$ & $0,12 \%$ & $406,9 \%$ \\
\hline Pýskaland & $0,01 \%$ & $0,19 \%$ & $0,42 \%$ & $-0,03 \%$ & $0,22 \%$ & $360,9 \%$ \\
\hline Meðaltal & $0,05 \%$ & $0,19 \%$ & $0,33 \%$ & $0,12 \%$ & $0,05 \%$ & $698,5 \%$ \\
\hline Miðgildi & $0,03 \%$ & $0,21 \%$ & $0,30 \%$ & $0,10 \%$ & $0,02 \%$ & $115,1 \%$ \\
\hline Fjöldi, $<0$ & 1 & 2 & 4 & 7 & 9 & 3 \\
\hline$>0$ & 28 & 27 & 25 & 22 & 20 & 25 \\
\hline
\end{tabular}

$t-1$ er síðasti viðskiptadagur mánaðar, $t+1$ sá fyrsti og svo framvegis. Hlutfall heildar vísar til pess hlutfalls heildarávöxtunar allra daga sem fram kom pessa fjóra daga. 